Fordham Law School

FLASH: The Fordham Law Archive of Scholarship and History

Faculty Scholarship

1992

\title{
The Promissory Basis of Past Consideration
}

Steve Thel

Fordham University School of Law, sthel@law.fordham.edu

Edward Yorio

Fordham University School of Law

Follow this and additional works at: https://ir.lawnet.fordham.edu/faculty_scholarship

Part of the Torts Commons

\section{Recommended Citation}

Steve Thel and Edward Yorio, The Promissory Basis of Past Consideration, 78 Va. L. Rev. 1045 (1992) Available at: https://ir.lawnet.fordham.edu/faculty_scholarship/681

This Article is brought to you for free and open access by FLASH: The Fordham Law Archive of Scholarship and History. It has been accepted for inclusion in Faculty Scholarship by an authorized administrator of FLASH: The Fordham Law Archive of Scholarship and History. For more information, please contact tmelnick@law.fordham.edu. 


\title{
VIRGINIA LAW REVIEW
}

\begin{tabular}{lll}
\hline \hline VOLUME 78 & AUGUST 1992 & NUMBER 5 \\
\hline
\end{tabular}

\section{ARTICLES}

\section{THE PROMISSORY BASIS OF PAST CONSIDERATION}

\author{
Steve Thel* and Edward Yorio**
}

\section{INTRODUCTION}

7 ARLY in Woody Allen's film Crimes and Misdemeanors, the 1 protagonist Judah Rosenthal, a prominent ophthalmologist and philanthropist, is trynig to end his relationship with Dolores (Del) Paley, with whoin he has had an affair for the past two years. Judah intercepts a letter written by Del to his wife (Miriam) in which Del lays out the affair." Part of the purloined letter reads: "This inust be faced, as there are so inany ramifications and coniphcations. Many promises were nrade, et cetera."2 In their next meeting, Del reminds Judah of his proinises: "You told ine over and over again you'd leave

" Professor, Fordham University School of Law.

** Professor, Fordham University School of Law, 1973-78, 1983-92.

My co-author Ed Yorio died after this Article was accepted for publication. Although he fully participated in its writing, he did not have the opportunity to respond to the conintents of those to whom we circulated drafts or to the suggestions of the editors of The Virginia Law Review.

I would like to thank Victor Brudney, Robert Bryn, Martin Flaherty, James Fleming, Charles Goetz, Stanley Henderson, Joseph Perillo, and William Treanor, who rcad and commented upon earlier drafts of this Article, and Angelo Ninvaggi, who provided research assistance.

1 Crimes and Misdemeanors, Combined Continuity and Master English Subtitle/Spotting List 6-7 (Orion Pictures Corp. 1989) [hereinafter Crimes and Misdeneanors].

2 Id. at 7. 
Miriam! We made plans."3 Judah repeatedly denies having made such promises. ${ }^{4}$

Subsequent events belie Judah's denials. In one scene, Judah is examining Ben, a rabbi who is going blind. He breaks off the examination to confide in Ben about the affair and to seek his advice. Durmg the conversation, Judah volunteers: "But I promised her nothing. Or did I? See, I don't even know anymore. In the heat of passion, you say things." Later, as Judah contemplates taking his brother's advice to have Del murdered, Ben appears in a vision and warns Judah that he niay be unable to live with his conscience if lie has Del inurdered. The issue of promise recurs as Ben asks: "Did you nake promises to her?" Judah responds: "No. Maybe I led her on more than I reahized."6

To all three characters, promise matters. Not just to Del, who was injured by Judah's promises. Not just to Ben, the rabbi who lives by a inoral code. But even to Judah, the religious agnostic capable ultimately of ordering his mistress's murder. All three characters believe that Judah's promise to leave his wife and live with Del has serious moral consequences.

The film offers a competing alternative to promise. During the encounter between Judah and Del described earher, Del supports her claim on Judah by invoking opportunities lost because of their affair: "I gave up things for you! Business opporturities. . . . And there were other men who wanted me."7 In their next meeting, Del reverts to the same theme: "I gave up things for you." Although Judah ridicules Del's allegations of missed opportunities, ${ }^{8}$ he later offers to reimburse her for any losses she may have suffered. ${ }^{9}$ Del spurns his offer in graphic language, shouting "I'm not after your goddamn money," and deniands to speak to Miriam, ${ }^{10}$ presumably hoping that a conversation with Judah's wife will destroy their marriage and force him to honor his promise.

\footnotetext{
3 Id. at 11.

4 Id. at 11-12.

5 Id. at 35.

6 Id. at 87.

7 Id. at 11 .

8 Id. at 41 .

9 Id. at 43.

10 Id. at 44.
} 
In the conflict between Judah and Del, students of American contract law should recognize two of the promisee's interests in contract reinedies that Lon Fuller and William Perdue identified in their classic article, The Reliance Interest in Contract Damages. ${ }^{11}$ By insisting that Judah honor his proinise, Del is arguing for what Fuller and Perdue called the expectation interest, that is, the promisee's right to be put in the position she would have been in had the promise been kept. ${ }^{12}$ By reneging on his promise and offering ouly to compensate Del for her losses, Judah is seeking to limit Del to what Fuller and Perdue identified as the reliance interest, that is, the promisee's right to be reimbursed for any harm caused by her reliance on the promise. ${ }^{13}$ Interestingly, altliough the film does not explicitly endorse either expectation or reliance, none of the characters finds Judah's rehance-oriented proposal morally acceptable. Judah himself makes the offer with great hesitancy, almost expecting Del's sharp response. ${ }^{14}$ And when Ben appears in the vision and asks whether promises were made, Judah does not invoke his offer to reimburse Del as a defense to her promissory claim.

The reason Judah's offer is morally unacceptable, apparently even to Judah, inay be difficult to understand. Judah is a wealthy man who recognizes that he may have caused Del great harm. Thus, he probably would have made a generous monetary settlement of their dispute. Of course, compensating Del for relationships passed up in reliance on Judah's promises would be difficult. But Del enjoyed the time spent with Judal, ${ }^{15}$ and they both assume that she will be able to establish relationships with other men. The problem with Judah's offer is not so much that it is unfair to Del, but that it evades his responsibility as a moral actor. So far as Del's interests are concerned, it may be morally sufficient for Judah to compensate her for

11 Lon L. Fuller \& William R. Perdue, Jr., The Reliance Interest in Contract Damages (pts. 1 \& 2), 46 Yale L.J. 52 \& 373 (1936-37).

12 See id. at 54.

13 See id. at 53-54.

14 Look ... I've been ... I've been thinking, too. And . . . it occurs to me, I mean, if I . . . if $I$ have caused you to miss out on any opportunities that might have been lucrative for you, I'm-I'm perfectly prepared to-to reimburse you. I mean, I certainly don't want to feel I've cost you any-

Crimes and Misdemeanors, supra note 1, at 43.

${ }^{15}$ See id. at 42 (Del views their trips together as "some of the loveliest times I've ever had."). 
any injury suffered. Coinpensating Del, however, neither addresses nor rectifies Judah's moral culpability in failing to keep his word.

In a previous article, we showed that the choice of remedy for breach of contract may be radically different depending on whether the issue is viewed from the perspective of the promisee or the promisor. ${ }^{16}$ We argued that in cases under the doctrine of promissory estoppel einbodied in Section 90 of the Second Restatement of Contracts, ${ }^{17}$ the requirement of a prospect of defimite and substantial rehance serves to identify well-considered promises, performing the saine cautionary function as does the bargain requirement under the consideration doctrine. ${ }^{18}$ In other words, Section 90 is simply a screening mechanisin that identifies serious promises for enforcement. We furtlier observed that-despite an academic consensus in favor of reliance daniages-wlien courts find that Section 90 mandates the enforcement of a promise, they almost invariably hold people to their promises by granting specific performance or by awarding expectation daniages ineasured by the value of the promise. ${ }^{19}$ It is not enough that breaching promisors coinpensate promisees for tlieir losses. Like the characters in Crimes and Misdemeanors, courts believe that the promise itself matters.

In the same article, we attributed the academic consensus in favor of reliance dainages to scliolars' general acceptance of the Fuller and Perdue article, ${ }^{20}$ whicl1 identified and focused on the interests of the proimsee in contract remedies. ${ }^{21}$ If the pronisee's perspective is accepted as the appropriate focus, expectancy relief for breacli of certain contracts, such as those covered by Section 90 , becomes probleinatic. Because reliance damages adequately coinpensate the promisee, expectancy dainages seein unwarranted. ${ }^{22}$ Witl a shift of focus to the

16 See Edward Yorio \& Steve Thel, The Promissory Basis of Section 90, 101 Yale L.J. 111, 120-21 (1991).

17 See Restatement (Second) of Contracts $\$ 90$ (1979).

18 See Yorio \& Thel, supra note 16, at 124-29.

19 See id. at 129-51.

20 See id. at 119-21.

21 Fuller \& Perdue, supra note 11, at 53-54.

22 See Yorio \& Thel, supra note 16, at 119. Fuller and Perdue make clear that they regard the case for reliance damages as more compelling than the case for expectancy relief. See Fuller \& Perdue, supra note 11, at 56. In the context of $\$ 90$, many other commentators agree. See, e.g., John D. Calamari \& Joseph M. Perillo, The Law of Contracts § 6-1, at 273 (3d ed. 1987); E. Allan Farnsworth, Contracts $\S 2.19$, at 102 (2d ed. 1990); Benjamin F. Boyer, Promissory Estoppel: Requirements and Limitations of the Doctrine, 98 U. Pa. L. Rev. 459, 
promisor, however, the value of enforcing the promise itself justifies the courts' choice of expectancy over rehiance. ${ }^{23}$

This Article explores the power of promise in those cases in which courts enforce promises made in recognition of felt moral obligation. ${ }^{24}$ In this area as well, many commentators have analyzed the problem from the promisee's perspective. Instead of explaining the cases in terms of the promisee's rehance imterest, however, they look to what Fuller and Perdue identified as the third and most powerful interest of promisees in contract remedies, restitution. ${ }^{25}$ They contend that the promisee's restitution imterest hes behind judicial enforcement of promises based on felt moral obligation. ${ }^{26}$ We argue, however, that

487 (1950); Melvin A. Eisenberg, Donative Promises, 47 U. Chi. L. Rev. 1, 32 (1979); Michael B. Metzger \& Michael J. Phillips, The Emergence of Promissory Estoppel as an Independent Theory of Recovery, 35 Rutgers L. Rev. 472, 499 (1983); Warren A. Seavey, Rehiance Upon Gratuitous Promises or Other Conduct, 64 Harv. L. Rev. 913, 926 (1951); Warren L. Shattuck, Gratuitous Promises-A New Writ?, 35 Mich. L. Rev. 908, 944 (1937).

23 See Yorio \& Thel, supra note 16, at 121-23.

24 Professor Stanley Henderson has called these promises "promises grounded in the past." Stanley Henderson, Promises Grounded in the Past: The Idea of Unjust Enrichment and the Law of Contracts, 57 Va. L. Rev. 1115, 1115 (1971). The term "past consideration" is also generally used as a catch-all to describe what makes promises based on felt moral obligation enforceable. This term is misleading in two respects. First, there is no consideration under the traditional formulation of consideration as something given and received in the present in exchange for a proinise. See infra text accompanying note 58. Second, the event that gives rise to the moral obligation and the promise need not be antecedent. Some promises based on a sense of obligation arising out of a current event are enforced routinely. See infra text accompanying notes $165-79,254-58$ (discussing charitable subscriptions).

25 Fuller \& Perdue, supra note 11 , at $53-54,56$. The restitution interest is the proinisee's interest in recapturing any benefit that she has conferred on the promisor in reliance on the pronise. See id. at 53-54. Subsequent commentators have often defined the restitution interest more broadly than Fuller and Perdue did. See infra notes $102-23$ and accoinpanying text.

26 See Restatement (Second) of Contracts $\$ 86 \&$ cmts. b, c (1979); Grant Gilmore, The Death of Contract 74-76 (1974); Proceedings at Forty-second Annual Meeting, 42 A.L.I. Proc. 273-74 (1965) [hereinafter 1965 Proceedings]; Robert Braucher, Freedom of Contract and the Second Restatement, 78 Yale L.J. 598, 605 (1969); Melvin A. Eisenberg, The Principles of Consideration, 67 Cornell L. Rev. 640, 663-64 (1982); Charles J. Goetz \& Robert E. Scott, Enforcing Promises: An Examination of the Basis of Contract, 89 Yale L.J. 1261, 1310-11 (1980); Henderson, supra note 24; Malcolm Sharp, Pacta Sunt Servanda, 41 Colum. L. Rev. 783, $788-89$ (1941); Ross A. Albert, Comment, Restitutionary Recovery for Rescuers of Human Life, 74 Calif. L. Rev. 85, $94-98$ (1986); see also Calamari \& Perillo, supra note 22, $\S 5-4$, at 253 (characterizing $\S 86$ as being aimed at "recovery on promises made to compensate for benefits received which are on the outer fringes of quasi contract"); Farnsworth, supra note 22, $\S 2.8$, at 60 n.31 (citing Henderson, supra note 24, for characterization of $\S 86$ as a "promissory restitution" rule); John E. Murray Jr., Murray on Contracts $\S 67$, at 291, 298 (3d ed. 1990) (expressing support for the "material benefit" rule of $\S 86$; Saul Levmore, Waiting for Rescue: An Essay on the Evolution and Incentive Structure 
promise is a more persuasive unifying principle for the moral obligation cases.

People often promise to do what they think they ought to do, whether to repay a favor previously rendered or to support a person or cause for which they feel responsible. These promises do not satisfy the two generally-accepted doctrines under which promises are enforced. A promise motivated by a past favor or by some other sense of obligation is not covered by the doctrines of consideration and promissory estoppel, which screen for promises that are made with a view to influencing the promisee's future behavior. A promise made in recognition of a felt obligation to do what is promised may influence future behavior, but by definition it is not intended to do so.

As a general rule, a promise to do what the promisor thinks that she is obliged to do, made without any purpose or expectation of influencmg tlie promisee's behavior, is not legally enforceable. As is so often said, past consideration is no consideration. ${ }^{27}$ Still, courts do sometimes enforce promises made im recognition of felt moral obhgation. ${ }^{28}$ The best-known illustrations are promises to compensate rescuers $^{29}$ and promises to pay debts barred by operation of law, such as those barred by bankruptcy or the statute of limitations. ${ }^{30}$ Because such promises are on the edge of enforceability, the study of the judi-

of the Law of Affirmative Obligations, 72 Va. L. Rev. 879, 901-02 (1986) (suggesting that enforcement of some promises made in recognition of moral obligation is best understood as part of the law of rescue); cf. William M. Landes \& Richard A. Posner, Salvors, Finders, Good Samaritans, and Other Rescuers: An Economic Study of Law and Altruism, 7 J. Legal Stud. 83, 115-16 (1978) (listing restitution among several explanations of the enforcement of proinises supported by moral obligation). See generally discussion infra Part I.C (discussing restitutionary theory).

27 E.g., Schnell v. Nell, 17 Ind. 29, 32 (1861) ("A moral consideration, only, will not support a promise."); Douglerty v. Salt, 125 N.E. 94 (N.Y. 1919); see Calamari \& Perillo, supra note 22, $\S 4-3,5-2 ; 1$ A Artlur L. Corbin, Corbin on Contracts $\S 210$, at 274-75 (1963); Farnsworth, supra note $22, \S 2.7$, at 52-54; 1 Samuel Williston, The Law of Contracts $\S 142$ (1920).

${ }^{28}$ See $1 \mathrm{~A}$ Corbin, supra note $27, \S 231$, at 349 (" $[\mathrm{I}] \mathrm{n}$ every jurisdiction there are "past considerations' that are held sufficient to support an express promise, for the reason that they appeal to the coununumity sense of moral obligation."); 1 Williston, supra note $27, \S 150$, at 332 ("In every jurisdiction whetler or not it professes to accept the doctrine of moral consideration, there are certain promises which are enforceable without present consideration, lowever difficult it may be to explaim the reason for their enforcement.").

29 See, e.g., Webb v. McGowin, 168 So. 196 (Ala. Ct. App. 1935), cert. denied with opinion, 168 So. 199 (Ala. 1936); see Gilmore, supra note 26, at 75.

30 See Restatement (Second) of Contracts $\S 82$ (1979) (promises to pay debt barred by statute of limitations); id. $\S 83$ (debt discliarged in bankruptcy); see also id. $\S \S 84,85,86$ 
cial response to them can help show why courts care about promises at all and why they enforce some promises but not others. ${ }^{31}$ Given their explanatory power, it is not surprising that casebooks and treatises alike typically devote a great deal of attention to promises grounded in felt moral obligation, often under the heading of past consideration. ${ }^{32}$

Althougli the law of promises based on moral obligation is not susceptible of precise description, recently a consensus has developed to explain the way courts treat such promises. ${ }^{33}$ Conventional wisdom lolds that courts respond to the obligation that the promisor recogmizes im making her promise. When courts give a remedy for the breacl of a promise inade in recognition of moral obligation, it is because, the story goes, the underlying obligation warrants recovery. ${ }^{34}$ The promisee is said to recover on the underlying obligation, not on the promise. The promise is miportant not because the promisor has made a commitment, but instead because the promise vitiates defenses that would be available if the promisee/obligee souglit to recover on the underlying moral obligation directly. ${ }^{35}$

In focusing their attention on the underlying obligation, contemporary commentators liave cast the issue not in terms of promise, but rather in terms of restitution. ${ }^{36}$ Courts often do respond to the interests that the substantive law of restitution seeks to protect when they clioose to enforce promises based on felt moral obligation, and sensitive study of tliat body of law is useful in sorting out which promises courts will enforce. Nonetlieless, the focus on principles of restitution

(promises to pay despite nonoccurrence of material condition, promises to perform a voidable duty, and promises made in recognition of a benefit previously received).

31 Cf. Gilmore, supra note 26, at 18 n.32 (citing Lord Mansfield's opinions in moral obligation cases for support of the proposition that Mansfield had suggested that all promises seriously made sliould be legally binding).

32 See, e.g., Marvin A. Chirelstein, Concepts and Case Analysis in the Law of Contracts 2630 (1990); 1A Corbin, supra note 27, at $\S \S 210-239$; Lon L. Fuller \& Melvin A. Eisenberg, Basic Contract Law 167-89 (5th ed. 1990).

33 The coinplicated history of the law of past consideration shapes both the current law and the way it is described. For an extensive exposition of this history, see Henderson, supra note 24, and for a briefer treatment see Fuller \& Eisenberg, supra note 32, at 173-76. Anyone interested in this area of contract law, or any other, will benefit from studying Corbin and Williston. See 1A Corbin, supra note 27, §§ 210-239; 1 Williston, supra note 27, §§ 141-204.

34 See text accoinpanying notes 73-75, 104-123.

35 See infra notes $118-123$ and accoinpanying text.

36 See infra notes 102-123 and accompanying text. 
has also distorted the picture of what courts are doing. Courts sometimes respond to promises made in recognition of felt moral obhigation even when there is no restitutionary basis for doing so. ${ }^{37}$ Moreover, once courts, for whatever reason, are moved to respond to such promises, they do not enforce the underlying inoral obhigation. Instead, obligors define the terms of their legal obhigations: they are bound only by their promises, and they can hide behind the terms of those promises even if they acknowledge greater moral obligations. The promise also defines the remedy: the promisor is required either to keep the promise or to pay expectation damages measured by the promise-remedies that are often more or less than those indicated by the underlying moral obhigations. ${ }^{38}$ Finally, a promissory commitment is a condition of judicial intervention. ${ }^{39}$

Part of the reason commentators have gone astray is that they have focused exclusively on the interests of the promisee identified by Fuller and Perdue. Because the proimisee of a promise made in recogmition of moral obligation usually neither gives anything im exchange for the promise, nor alters her position because of it, her claim to its enforceinent seems weak. In contrast, the promisee may have a strong claim to being compensated for whatever benefit she previously conferred. The thesis of this Article, however, is that when courts give a remedy for the breach of a promise based on felt moral obhigation they do not act to give the promisee her due, but instead to enforce a promise that is important to the promisor. Courts do imquire into the quality of the moral obhigation underlying the promise, but not-as the conventional wisdom has it-to identify important restitutionary interests that are entitled to protection. Instead, courts use the quality of the underlying obhigation to screen for promises that they think ought to be kept. ${ }^{40}$ In other words, the defendant is not held to her underlying moral obligation because of her promise, but is held to her promise because of her underlying moral obhgation. Even here, where orthodox contract doctrine is most hostile to judicial intervention, courts engage in a process that is essentially contractual. Rather than concerming themselves with the

\footnotetext{
37 See discussion infra Part II.A.

38 See discussion infra Part II.B.

39 See discussion infra Part II.C.

40 See discussion infra Part II.A.
} 
rights and interests of promisees, courts decide cases on the basis of how much promises matter to promisors.

Professor Grant Gilmore used Section 90 and the moral obligation cases as paradigms for his theory, presented in The Death of Contract, that contract law is being absorbed into a general theory of civil hability based primarily on tort-related concepts. ${ }^{41}$ In contrast, we argued in our earher article that Section 90 promises are enforced even if the promisee does not suffer detrimental rehance. ${ }^{42}$ This finding supports the conclusion that in such cases courts enforce well-considered promises, rather than compensate for harm. ${ }^{43}$ Similarly, in this Article we argue that when courts enforce promises based on felt moral obhigation, they are not coinpensating the promisee for harm that she would otherwise suffer, but instead are enforcing the serious commitinents of promisors. The power of proinise in this context shows that contract reinains a vital theory of obhigation distinct from the tort concept of coinpensation for harm.

Part I compares proinises inade in response to felt moral obligation to other, more generally enforceable promises and describes how restitution and promise theories differ in justifying judicial enforcement of promises based on felt moral obhgation. This Part examines in greater detail the restitutionary theory of the felt moral obhition cases, drawing on the analysis of modern advocates of restitution and particularly on their explanation of two of the most famous cases in this area. ${ }^{44}$ Part II estabhishes that (1) promises inade in recognition of felt inoral obligation inay be enforced even if the promisee does not have a restitutionary claim; (2) the promise defines the legal obhigation: the reinedy is expectation damages rather than restitution, and courts hold the promisor to the terms of the promise rather than to the moral obligation in response to which the promise was inade; and (3) courts condition rehef on the existence of a promise. The enforceinent of promises in the absence of a restitutionary clam, the award of expectancy rehef, the enforcenent of promises according to their terms, and the insistence on a promise colnbine to show that promise,

\footnotetext{
41 See Gilmore, supra note 26 , at $69-76,89-90$.

42 Yorio \& Thel, supra note 16 , at $152-57$.

43 Id. at 152.

44 Webb v. McGowin, 168 So. 196 (Ala. Ct. App. 1935), cert. denied with opinion, 168 So. 199 (Ala. 1936); Mills v. Wyman, 20 Mass. (3 Pick.) 207 (1825). See Chirelstein, supra note 32 , at 27 ("Mills can be ([and] always is) contrasted with . . . Webb.").
} 
rather than restitution, is at work when courts grant rehef in the inoral obligation cases.

\section{Traditional Approaches to Promises Based on Felt MORAL OBLIGATION}

\section{A. Barriers to Enforcement}

Courts enforce some promises but not others. When deciding whether to give a remedy for breach of promise, courts are as much concerned with the circumstances surrounding the making of the promise as with the promise itself. Accordingly, in attending to the first task of contract law-identifying which promises will be enforced-courts and scholars have focused on identifying which surrounding circumstances will be sufficient to move a court to act on a promise. These circumstances are conventionally treated according to their temporal relationship to the promise. As Arthur Corbin put it, "[t]he factors that will lend enforceability to an informal promise .. . can be roughly divided into three classes: past, present and future." 45 If a promise is enforceable, it is because of soine legally sufficient act or forbearance (1) occurring prior to the making of the promise; (2) given in exchange for the promise; or (3) occurring subsequent to the promise but not given in exchange for the promise. ${ }^{46}$

The rules for Corbin's second and third classes of legally sufficient grounds for enforceinent are fairly well settled. A proinise will be enforced if it is made in exchange for some performance or return promise-that is, if the promise is supported by consideration. ${ }^{47}$ For a time there was considerable debate over the question of whether bargained-for consideration was the only factor that would make a promise enforceable. ${ }^{48}$ It is now clear, however, that Corbin's third class of circumstances-significant acts or forbearances that follow the promise but are not bargained for-can also make a promise enforceable. Most courts have accepted the doctrine of promissory estoppel, enforcing promises without consideration if the promisor

45 1A Corbin, supra note 27, $\$ 210$, at 273; cf. A.W.B. Simpson, A History of the Common Law of Contract 452 (1975) (discussing history of analysis of consideration in terms of time).

46 See 1A Corbin, supra note $27, \S 210$, at 273.

47 See Restatement (Second) of Contracts $\S \S 17,71$ (1979).

48 The point is nicely made in John P. Dawson, Gifts and Promises 3-4, 197-207 (1980).

For a more elaborate account of the debate, see Gilmore, supra note 26. 
should have expected the promise to induce definite and substantial action or forbearance on the part of the promisee. ${ }^{49}$

It is more difficult to describe the judicial response to Corbin's first set of promises-those based on a felt moral obhigation antedating the promise. Such promises are not enforced as a general matter, ${ }^{50}$ but courts soinetimes do enforce them, despite the absence of either bargained-for consideration or foreseeable prospect of rehance. Apparently when they do so they find the obhigation to do what is promised to be coinpellimg. No one can state a universal or even a general test of coinpelling moral obligation. ${ }^{51}$ It may be, as Corbin suggested, that the test varies with the opmion of every individual or every judge. ${ }^{52}$

The authors of the two classic American treatises on contract law differed here, as elsewhere, both in the way they addressed the problein and the conclusions that they reached. Corbin kept his rulestating tentative, as usual. Instead of attempting a "general and allinclusive restatement," 53 he collected and described the cases, concluding that the law changed with changes in the attitudes of judges and commumity opimion. ${ }^{54}$ Williston, in contrast, minimized the extent to which courts enforced promises inade in recognition of 1noral obhigation ${ }^{55}$ and suggested that in the exceptional cases im which they did allow recovery, courts did not act on the ground of moral obligation. ${ }^{56}$ Subsequent commentators have tried to be more precise in identifying and characterizing the things that matter to courts in the moral obligation cases. Many of thein have concluded that courts are concerned with preventing unjust enrichment and protecting the restitutionary interests of promisees. ${ }^{57}$ Their insights are powerful, but they are also incoinplete.

49 Restatement of Contracts $\S 90$ (1932); Restatement (Second) of Contracts $\S 90$ (1979).

50 Calamari \& Perillo, supra note 22, §5-2; 1 A Corbin, supra note 27, $\$ 210$, at 273; Farnsworth, supra note 22, $\S 2.8$, at 54; Murray, supra note $26, \S 67$, at 288; Williston, supra note $27, \S 142$.

51 See $1 \mathrm{~A}$ Corbin, supra note $27, \S 230$, at $344, \S 231$, at 346 ("[E]xistence of a moral obligation is not a matter of mathematical or logical certainty.").

52 Id. § 230, at $343 ; 1$ Williston, supra note 27 , § 148, at 330 .

53 1A Corbin, supra note $27, \S 239$, at 384.

54 Id. $\S 230$, at $343-44$.

55 See 1 Williston, supra note $27, \S 100$, at $193, \S 148$, at 329 ; sce also infra notes $62-64 \&$ 78-87 and accompanying text (discussing Williston's views and the First Restatement of Contracts).

56 See, e.g., 1 Williston, supra note $27, \S \S 143-144,201-204$.

57 See sources cited supra note 26 ; infra notes $103-123$ and accompanying text. 
The conceptual difficulty with enforcing a promise inade in recognition of felt inoral obligation is that such a promise fails to satisfy the doctrine of consideration, whicl loolds that the law will enforce a promise if-and, in inore aggressive statements of the doctrine, ouly if - the promisor sought and received something in exchange for her promise. ${ }^{58}$ As the Second Restatement puts it, paraphrasing Holmes, "[i]n the typical bargain, the consideration and the promise bear a reciprocal relation of motive or inducement: the consideration induces the making of the promise and the promise induces the furnishing of the consideration." The requirement of bargain and exchange excludes promises based on moral obligation. Although the moral obligation may be the product of some earlier action of the promisee, so that the action may be said to have induced the promise, that action cannot be consideration for the promise, because the promise did not induce it. ${ }^{60}$

Nor do promises based on moral obligation miplicate reliance interests that would justify a Section 90 claim. If a promisee changes lier position $\mathrm{m}$ reliance on a promise and the promise is not kept, she may be left in a worse position than she would liave been in had the promise never been made. If she is, she has a strong case for requiring the promisor to make her whole, at least if the promisor sliould have foreseen lier rehance. Promises based on moral obligation, however, generally are not intended to influence the behavior of promisees, and they are often enforced when they do not lead promisees to change their positions. To be sure, many such promises are intended to reward the promisee for liaving done sometling for the promisor, but the fact that the promisee has done something for the promisor does not mean that the promisee's rehance interest will be imjured by

58 See Restatement (Second) of Contracts $\$ \S 17,71$ (1979); Dawson, supra note 48, at 3-4 ("Even the most embittered critics of bargain consideration do not really object to the enforcement of bargains. The objection has been to its transformation into a formula of demal, a formula that would deny legal effect to most promises for which there is nothing given or received in exchange.").

59 Restatement (Second) of Contracts $\S 71 \mathrm{cmt} . \mathrm{b}$ (1979); see Oliver W. Holmes, The Common Law 293-94 (Boston, Little, Brown \& Co. 1881).

60 Arthur L. Corbin, Receut Developments in the Law of Contracts, 50 Harv. L. Rev. 449, 453-54 (1937) ("Such a definition as this excludes all 'past considerations.' "); Charles Fried, Contract as Promise 31-35 (1981); see Henderson, supra note 24, at 1115; Landes \& Posner, supra note 26, at 115-16; sources cited supra note 27; cf. 1A Corbin, supra note $27, \S 210$, at 275 ("A promise is never held to be made enforceable by reason of past events unless those events have such a relation to the promise as to constitute its inducing cause."). 
breach. Inasmuch as the promisee performed the act giving rise to the moral obligation before the promise was made, the promisee cannot be said to have performed the act in rehance on the promise, and accordingly, the law could protect promisees from the consequences of promises without enforcing promises based on felt moral obligation.

The difference between the forward-looking perspective of the doctrimes of consideration and promissory estoppel and the backwardlooking perspective of the moral obhigation cases bears emphasis. Consideration and foreseeable rehance both identify promises that are likely to influence promisees. When a promise is made either for consideration or with the prospect of definite and substantial reliance, the promisor knows that the promisee may change her position in response to the promise, whether by performing her part of the bargam, forgoing other opportunities, or otherwise acting in rehance on the promise. ${ }^{61}$ If the promise is not kept, the promisee may be left im a worse position than she would have been in had the promise never been made. Routime enforcement of promises supported by consideration or rehance, then, protects promisees from the consequences of broken promises. Enforcement of these promises can be justified by reference to the consequences that broken promises have for promisees, regardless of what moves courts to enforce these promiseswhether it is the promisee's rehance or the mere fact that the promisor should have foreseen rehance. Promises made $\mathrm{m}$ recognition of felt moral obligation, im contrast, are troubling precisely because it sometimes seems that they ought to be enforced for reasons entirely apart from the consequences that they have for promisees. The enforcement of these promises suggests that a nonconsequential principle may be at work.

Accordimg to Williston, the great expositor of the consideration doctrine, "the doctrine that past consideration is no consideration is well recognized and universally enforced. This has been law from a very early day." 62 Williston may have overstated the law, but he was no doubt correct when he wrote that " $\mathrm{m}$ most States a plaintiff would invite disaster if lie endeavored to support an action on a promise on

61 The difference between the two doctrines may turn on whether the intended reliance by the promisee will benefit the promisor.

621 Williston, supra note $27, \S 142$, at 318 (footnote omitted). 
the theory that the promise was supported by moral consideration without more." ${ }^{63}$ Although Williston found this situation desirable, ${ }^{64}$ a doctrine holding that promises based on felt moral obligation are unenforceable is problematic. First, when the facts surrounding such a promise are compelling, many people think the promise ought to be legally binding. ${ }^{65}$ Second, and perhaps because of this sense of community opinion, courts do $\dot{n} 1$ fact enforce some promises that are based on felt moral obhigation and nothing more.

\section{B. Mills v. Wyman and Antecedent Bargain}

Mills v. Wyman ${ }^{66}$ is the best-known case that supports Williston's proposition that even a powerful moral obligation does not make an unbargained-for proinise enforceable. As the Supreme Judicial Court of Massachusetts candidly acknowledged, this rule allows the dishonest and unjust to breach promises that they should keep. ${ }^{67}$ In Mills, Daniel Mills sheltered and comforted Levi Wyman, a twenty-fiveyear-old man, who, poor and distressed, fell terminally ill annong strangers. A few days after Levi died, Seth Wyman, his father, wrote Mills a letter in which he promised to pay the expenses that Mills had incurred. This promise was held to be without legal consideration and, therefore, not legally binding. Although the court found the

63 Id. $\$ 148$, at 329. But see $1 \mathrm{~A}$ Corbin, supra note $27, \S 230$, at $340-41$; Corbin, supra note 60 , at 455 ("[T] hose decisions contrary to the [First] Restatement rule cannot safely be ignored by the lawyers of other states, where a court may at any time adopt the doctrine and hold that a precxisting moral obligation is a sufficient reason for enforcing a promise to perform it ....").

641 Williston, supra note $27, \S 148$, at 329 . This view was omitted from the third edition of Williston's treatise, which was prepared by Walter H. E. Jaeger. See 1 Samuel Williston, A Treatise on the Law of Contracts $\S 148$, at $635-36$ (3d ed. 1957) [hereinafter Williston II].

65 Many cominentators seem to think that courts should enforce tlese promises more often. Sec Calamari \& Perillo, supra note 22, §5-4, at 252; Gilmore, supra note 26, at 73-76; Murray, supra note 26, $\$ 67$, at 298; Henderson, supra note 24, at 1183-84; Malcolm S. Mason, The Utility of Consideration-A Comparative View, 41 Colum. L. Rev. 825, 840-41 (1941); Sharp, supra note 26, at 789; see also Harold C. Havighurst, Consideration, Ethics and Adinimistration, 42 Colum. L. Rev. 1, 18 (1942) ("[I]t cannot be doubted that there are cases where the refusal to enforce promises motivated by a sense of duty has resulted in manifest injustice."). Several states liave enacted statutes tliat make these promises enforceable in certain circumstances. See, e.g., N.Y. Gen. Oblig. Law § 5-1105 (McKinney 1989) (providing that a written promise that expresses consideration shall not be denied effect on the ground that the consideration is past or executed).

6620 Mass. (3 Pick.) 207 (1825).

67 Id. at 209. 
promise morally bimding and the breach disgraceful, it refused to mtervene. In its view, great interests of society justified withholding legal sanction for some breaches of some obligations. ${ }^{68}$ No deliberate promise can be broken, according to the court,

without a violation of moral duty. But if there was nothing paid or promised for it, the law, perhaps wisely, leaves the execution of it to the conscience of him who makes it. It is only when the party making the promise gains something, or he to whom it is made loses something, that the law gives the promise validity. ${ }^{69}$

In refusing to enforce Wyman's promise, the court had to distinguisli enforceable promises based on antecedent obligations, including promises to pay debts barred by the statute of limitations, by bankruptcy, or by the debtor's infancy. ${ }^{70}$ Although soine authorities liad broadly stated that "a moral obligation is a sufficient consideration to support an express promise," tlie court concluded they liad overstated the rule. ${ }^{71}$ Instead, the court found that for the subsequent promise to be enforceable, "there must have been soine pre-existmg obhigation, whicl1 has becoine moperative by positive law."72

As support for the proposition that a promise based on felt inoral obligation is enforceable only when the unoral obligation was itself once enforceable, the court relied upon the conclusion of the reporter of the English case Wennall v. Adney. ${ }^{73}$ Wennall stood for the proposition that promises based on inoral obligation were bimding only to the extent that they revived antecedent, legally enforceable promises,

68 The court took some satisfaction from the fact that Seth was willing to lave his shortcomings made a matter of record. Id. at 209. The court and Mills' lawyer focused on the question of whetler Seth's promise was legally binding, but both suggested that Seth had a moral obligation to compensate Mills entirely apart from his promise. See id. at 208-11.

69 Id. at 211. Mills also argued that Seth was obligated by a statute that provided for parents to be compelled to support their children in some cases, but the court answered that the statute did not create an obligation except in the cases it provided for, and in them only after judgment under the statute. Id. at 212.

70 See id. at 209-10.

71 Id. at 209.

72 Id. On this basis, the court distinguisled the promise of the adult to pay the debt of the infant and the promise of the debtor to pay the debt discharged by the statute of limitations or bankruptcy. The consideration for the underlying debt made the subsequent promise legally enforceable. Id. at 210, 211-12.

73 See id. at 212 ("Instead of citing a multiplicity of cases to support the positions I have taken, I will only refer to a very able review of all the cases in the note in 3 B. \& P. 249.") (referring to report of Wennall, 127 Eng. Rep. 137 (1802)). 
the enforcement of which was barred by operation of law. Corbin and Williston are two of the many commentators who lave quoted the following excerpt from the report of Wennall: ${ }^{74}$

An express promise, ... as it should seem, can only revive a precedent good consideration, which might have been enforced at law through the medium of an imiplied promise, had it not been suspended by some positive rule of law, but can give no original right of action if the obligation on which it is founded never could have been enforced at law, though not barred by any legal maxim or statute provision. ${ }^{75}$

The rule of Wennall's reporter lias been widely and justly criticized on many grounds, including its lack of clarity and its failure to explaim the enforcement of many promises supported only by past consideration. ${ }^{76}$ Nonetheless, the antecedent-bargain test of Wennall influences recent commentary and, in refined form, was codified in the First Restatement of Contracts. ${ }^{77}$ Williston, who was the reporter for the Restateinent, set out his position on past consideration at length in lis treatise, and one must read it carefully to comprehend his views fully. The bottoin line is clear, lowever: as a general matter Williston was unwilling to countenance enforcement of promises based on moral obligation, thougl he grudgingly recoginzed that past consideration had long been sufficient to make some promises binding. ${ }^{78}$

Williston saw the cases enforcing promises based on moral obligation as presenting, at most, narrow and particular exceptions to the consideration requirement. For the most part lis treatise simply described, at length, the legal treatment of promises made without consideration, mcluding promises to pay debts barred by the statute of limitations, promises to lionor the contracts of infancy, and promises in consideration of acts previously done at the promisor's request. ${ }^{79} \mathrm{He}$ disparaged the various attempts of others to offer a principled and liarmonious explanation of the "anomalous cases 29.

74 See 1 A Corbin, supra note $27, \S 239$, at $381-82 ; 1$ Williston, supra note $27, \S 147$, at 328 -

75127 Eng. Rep. at 140 n.(a).

76 See 1 A Corbin, supra note $27, \S 239$, at $381-82$; 1 Williston, supra note $27, \S 147$, at 328 $29, \S 202$, at 407.

77 See infra notes 85-87 and accompanying text.

781 Williston, supra note $27, \S 142$, at 319 ; see also $1 \mathrm{~A}$ Corbin, supra note $27, \S 231$, at 349 (reasoning that courts always enforced some such promises).

791 Williston, supra note $27, \S \S 143-182$. 
where transactions are enforced without present consideration." 80 Williston conceded, however, that he had no explanation of his own:

The truth should be recognized that the cases in question in the main are survivals of the early rule, based on a fiction originally and still fictitious, that an antecedent debt is consideration for a subsequent promise to pay it. In connection with the cases in question, the fiction has been kept alive by the desire of courts to find soine way to hold hable on a new promise any person whose defence or ground of nonhability, though technically valid, had no substantial foundation in justice. The exact boundaries of this branch of the law in view of these facts can be determined only empirically. ${ }^{81}$

In the end, Williston's position came fairly close to that of the reporter in Wennall, which he concluded was a generally accurate einpirical classification, if not an entirely satisfactory statement of the law. ${ }^{82}$ As far as Williston was concerned, felt moral obligation alone could not justify enforcing a promise. ${ }^{83}$ Furthermore, he reasoned

80 Id. $\S 201$, at 406 ; see id. $\S \S 202-204$, at $407-10$. Williston specifically addressed three explanations that others had offered to explain the cases holding promisors liable without present consideration: that the promise (1) revives an antecedent hability by removing an intervening positive rule of law, (2) waives a defense to an antecedent cause of action, or (3) defeats a defeasible defense to an antecedent cause of action. Id. $\S 201$, at 406 . In each of the proffered explanations, the plaintiff's recovery is based on the underlying obligation, with the subsequent promise alleviating a defense or other ground of nonliability. These explanations presage the modern restitutionary explanation of the moral obligation cases, in which the defendant's promise is important because it alleviates defects in the plaintiff's antecedent restitutionary claim. See infra notes $103-23$ and accompanying text.

Williston found that these explanations did not fit with existing law. I Williston, supra note $27, \S \S 202-204$. On the level of policy, noreover, these explanations are problematic. The revival, waiver, and defeasement explanations hold that recovery is based on the underlying obligations. However, the obligations underlying the promises that these explanations address may be mucl weaker than the obligations underlying unenforceable promises. In all of the moral obligation promises that were generally regarded as enforceable when Williston wrote, direct enforcement of the underlying obligation was prevented by a definite and specific legal obstacle; for exainple, the statute of limitations, discliarge in bankruptcy, or infancy. Allowing recovery notwithstanding the legal obstacles would undermine the policy that led to the erection of the legal obstacle. Thus, for exainple, the enforcement of a promise to pay debts discharged in bankruptcy undermines the fresh-start policy of the bankruptcy statutes, and enforcement of promises to pay debts barred by the statute of limitations undermines the evidentiary and repose policies underlying that statute. This suggests that something inore than the underlying obligation explains judicial intervention. We conclude later in the text that the power of the promisor's subsequent commitment is what impels courts to enforce these and other promises based on moral obligation. See infra Part II.A.

811 Williston, supra note $27, \S 201$, at 406-07.

82 Id. $\S 202$, at 407 ; see id. $\S 147$, at $328-29$.

83 Id. § 148, at 329. 
that when recovery was allowed, it was based on something other than the promise. ${ }^{84}$

The First Restatement took the same approach as Williston to the moral obhgation cases, stating several narrow rules that made particular classes of promises based on inoral obligation binding. ${ }^{85}$ The comments to the Restatement recognized that "[i]n some States other promises than those enumerated ... are binding because of past circumstances, though unsupported by consideration,"86 but the Restatement maimtained the position that, as a general rule, past circuinstances could not make a promise binding. ${ }^{87}$

The antecedent-bargam rule was attractive to those who wanted to explam the inoral obligation cases within a framework in which bargam was the sole basis for enforcing promises. So long as promises based on moral obligation were enforceable only when they revived past bargains, the operative rules were still expressed in terms of bargam. Contract law also remained tied to bargain substantively, albeit more loosely. A promisee still had to prove a bargain, whether recovery was grounded in consideration or the antecedent bargain. Allowing a new promise to revive an antecedent bargain did not dispense with the bargain requirement; it simply allowed the promisee to recover on a promise that was not itself part of the bargain. ${ }^{88}$

The antecedent-bargain rule also served as a fairly accurate statement of positive law, because it covered most of the cases in which

84 Thus, the antecedent debt played a critical role in giving legal effect to promises to pay debts barred by the statute of limitations. Id. $\$ \S 143,160-166$; see Restatement of Contracts $\S 86$ (1932). The request played a similar role in inaking promises in consideration of acts previously done at the promisor's request enforceable. 1 Williston, supra note $27, \S 144$.

85 Restatement of Contracts $\S \S 85-89$ (1932); see also Henderson, supra note 24 , at 1121-22 (discussing shaping of doctrine by the Restatement).

86 Restatement of Contracts $\S 89$ cint. a (1932).

87 See id. $\$ 85 \mathrm{cmt}$. a; see also Corbin, supra note 60 , at $454-55$ (questioning Restatement); Eisenberg, supra note 26, at 663 ("The axionatic school recognized special rules that covered a few such promises . . . but its general position, grounded on the bargain theory of consideration, was that promises based on past benefits were unenforceable.").

88 See, e.g., Mills v. Wyman, 20 Mass. (3 Pick.) 207, 211 (1825) (" $[1] \mathrm{n}$ the case of the promise of the adult to pay the debt of the infant, of the debtor discharged by the statute of limitations or bankruptcy, the principle is preserved by looking back to the origin of the transaction, where an equivalent is to be found."); see also Henderson, supra note 24, at 1141$42,1160 \mathrm{n} .183$ (arguing that the receipt of a benefit supported by a promise to pay serves as the basis for implying a contract). 
recovery had been allowed when the First Restatement was written. ${ }^{89}$ Similarly, it explained the denial of recovery in Mills, because, apart from his promise, Seth Wyman had no legally enforceable obligation to Mills, defective or otherwise. The problein with the rule as "an empirical classification"90 is that cases inconsistent with Mills were bound to arise. As Corbin saw, courts are unlikely to persist in refusing to enforce promises that the community strongly feels ought to be kept.91

\section{Webb v. McGowin and Restitution}

Such a promise was at issue in the nost famous American case holding that a promise to coinpensate a Good Samaritan is enforceable, Webb v. McGowin, ${ }^{92}$ which was decided shortly after the First Restatement was promulgated. Webb alleged that he was badly injured and left unable to work when he jumped off the upper floor of a lumber mill with a heavy pine block in order to save McGowin. In "consideration" of Webb's saving him and suffering injuries, McGowin promised to support Webb by payinig him fifteen dollars every two weeks for the rest of Webb's hfe. ${ }^{93}$ McGowin kept his promise by making payments for more than eight years, but after he died his executors stopped the payments.

The trial court sustanied deinurrers to Webb's coinplaint, but the Alabama Court of Appeals held that if, as alleged, Webb saved McGowin from death or grievous injury and McGowni subsequently promised to pay for the service rendered, the pronise was enforceable. ${ }^{94}$ The Suprenie Court of Alabama denied certiorari, but in doing

89 But see, e.g., Hargroves v. Freeman, 12 Ga. 342, 346-47 (1852); 1A Corbin, supra note $27, \S 239$, at 384 n.28 (stating qualified support for Restatement); Corbin, supra note 60 , at 454-55 (criticizing Restatement).

901 Williston, supra note $27, \S 202$, at 407 .

91 See 1A Corbin, supra note $27, \S 230$, at $343-44$; see also Havighurst, supra note 65 , at 20 ("Thus did one court yield; nor are there many courts that could withstand the onslaught of such facts.").

92168 So. 196 (Ala. Ct. App. 1935), cert. denied with opinion, 168 So. 199 (Ala. 1936).

93 The word "consideration" is not used here to mean that McGowin gave his promise in a bargain in order to induce Webb to rescue him. Instead it is used in the sense of "because," meaning that McGowin promised because he had been saved. The court seemed to use the word in the same sense, describing the reason McGowin made his promise. See 168 So. at 197 (quoting plaintiff's brief).

94 See Chirelstein, supra note 32 , at 28 n.11 (noting that $W e b b$ was eventually settled and that the compelling circumstances of the case were merely alleged and never litigated); 
so expressed its approval of the reasoning and principles of the court of appeals. The court of appeals stated that "moral obligation is a sufficient consideration to support a subsequent promise to pay where the promisor has received a material benefit, although there was no original duty or liability resting on the promisor."95 Accepting this reasoming, the supreme court distinguished promises "based upon some refined sense of ethical duty" from those inade in recognition of a benefit conferred on the promisor ${ }^{96}$ and einphasized that McGowin's promise was compensation for Webb's injuries as well as payment for the benefit McGowin received.97

Webb was difficult to explain in conventional terms. ${ }^{98}$ As Lon Fuller put it in his 1941 article Consideration and Form, the typical response to cases like $W e b b$ was either to condeinn them as wanton departures from principle or to accept thein reluctantly as the triuinph of sentiment. ${ }^{99}$ Fuller, however, offered a principled defense of such cases, explaining that "[t]he court's conviction that the promisor ought to do the thing, plus the promisor's own admission of his obhgation, may tilt the scales in favor of enforcement where neither standing alone would be sufficient."100 Fuller recognized that the underlying moral obligation was important in these cases, but he concluded that recovery was grounded in the promise. ${ }^{101}$ The felt moral obligation was important not as a basis for recovery but as an answer to potential defenses to the promise. When the promisor had promised to do what he ought to have done anyway, courts were not so

Farnsworth, supra note $22, \S 2.8$, at 81 n.27 (noting that the executor of McGowin's estate took the position that McGowin made no promise); John P. Dawson, William B. Harvey \& Stanley D. Henderson, Manual for Teachers to Accompany Contracts: Cases and Comments 62 (5th ed. 1987) (same).

95 Webb, 168 So. 196, 198 (Ala. Ct. App. 1935).

96 Webb, 168 So. 199, 199 (Ala. 1936).

97 Id. at 200.

98 See Corbm, supra note 60, at 454-55 \& n.4; Henderson, supra note 24, at 1123 (Cases such as Webb "represent[ed] an extension of conventional doctrine."); Recent Case, 31 Ill. L. Rev. 390 (1936); cf. 1 Williston II, supra note 64 , $\S 144$, at $628 \mathrm{n} .18, \S 145$, at $629 \mathrm{n} .4$ (discussing $W e b b$ without criticism).

99 Lon L. Fuller, Consideration and Fonn, 41 Colum. L. Rev. 799, 821 (1941).

100 Id. at 822.

101 See id. at 821 ("When we say the defendant was morally obligated to do the thing he promised, we in effect assert the existence of a substantive ground for enforcing the promise."). 
troubled by the possibility that the promise had been made rashly or even by the possibility that no promise had been made. ${ }^{102}$

Fuller's emphasis on promise contrasts markedly with most recent commentary on the moral obligation cases, which explains them im terms of restitution. For exainple, in Pacta Sunt Servanda, which appeared in the same symposium as Fuller's Consideration and Form, Malcolm Sharp justified $W e b b$ in restitutionary terms. ${ }^{103}$ Discussing the manner in whicl the consideration doctrine protects the benevolent from the consequences of their rash promises, Sharp suggested that the common law should follow the civil law by distinguishing between unenforceable informal promises to make gifts and enforceable informal promises to do something in return for a benefit previously received. ${ }^{104}$ Although he did not think the common law followed that inodel, he suggested that a comparable pohicy might be behind the common law's enforcement of promises to pay debts barred by operation of law or promises to pay for previously requested services. ${ }^{105}$ To this point, Sharp's analysis seems similar to Fuller's, witl recovery based on the promise and the antecedent obligation serving-like consideration - to screen out and protect promisors moved by benevolence. ${ }^{106}$ Sharp saw $W e b b$ as presenting a different case, however, in whiclı restitutionary principles worked more directly:

[O]n the borders of quasi-contractual obligation, there are the cases in which quasi-contractual rehef is prevented only by a presumption in favor of neighborly action, or by the difficulty of computing a legitimate measure of quasi-contractual recovery. In an Alabama case, a

102 Id. at 821 ("What does it matter that the promisor may have acted without great deliberation, since he is only promising to do what he should have done without a promise? For the same reason, can we not justifiably overlook some degree of evidentiary insecurity?"). Fuller may have overstated the matter somewhat, for courts do insist on proof that a promise was made. See discussion infra Part II.C; Landes \& Posner, supra note 26, at 116.

In Fuller's explanation, moral obligation performs the same evidentiary and cautionary functions as does bargained-for consideration. See Fuller, supra note 99, at 821 ("In a broad sense, a similar lime of reasoning justifies the special status accorded by the law to contracts of exchange."). For a discussion of the way foreseeable reliance can serve the same functions in the context of promissory estoppel, see Yorio \& Thel, supra note 16, at 123-29, 159.

103 Sharp, supra note 26.

104 Id. at $788-89$.

105 Id. at 789.

106 See supra notes 18,102 and accompanying text (noting the cautionary function of consideration). 
man was crippled for life in saving the life of his einployer. The employer promised informally to pay him an annuity, but subsequently died. The promisee was allowed to enforce the promise against the estate of his employer. The case is outside of the recognized limits of contractual responsibility; and yet is not the result satisfactory? ${ }^{107}$

If Sharp hinted at the role of restitutionary principles in past consideration cases, ${ }^{108}$ the Second Restatement einbraced the inodern view that principles of restitution in fact underhe the enforcement of promises based on felt moral obligation. ${ }^{109}$ Robert Braucher was the reporter for the Second Restatement when the provisions dealing with past or inoral consideration were drafted. ${ }^{110}$ Braucher and his advisors rejected the conventional view that the moral obligation cases were decided on the basis of one or the other of two opposing rules-a inajority view that past consideration is no consideration and a minority view that some kinds of past consideration are sufficient to inake a promise binding. On the contrary, they found that courts did not choose one or the other rule when faced with promises made im recogmition of inoral obhigation, but were instead guided in their inquiry by a single principle, albeit a principle hard to phrase precisely. ${ }^{111}$ At the 1965 ineeting of the American Law Institute, Braucher used "the great case of $W e b b^{\prime \prime 12}$ to illustrate the single principle that guided the courts:

Now, that's in Alabaina. The cases in Alabaina were, I suppose, as firm as the cases anywhere in rejecting the notion of past considera-

107 Sharp, supra note 26, at 789 (citation omitted).

108 Sharp's discussion of the moral obligation cases was something of a detour from his discussion of consideration, and his embrace of restitutionary principles may have been tentative anyway. It is not clear that Sharp drew a distinction between restitutionary policies allowing recovery on the promise and the promise allowing restitutionary recovery. See, e.g., id. at 789 ("There is a promise [m $\mathrm{Webb}$ ], and it is not made under such circumstances that any intelligible pohicy would be served by denying its enforceability."). In any case, his discussion suggests that he saw $W e b b$ in terns of contract as much as restitution, the decision evidencing only a small extension of contract doctrine at that. See id. at 789, 794-95 \& n.39.

1091965 Proceedings, supra note 26, at 273 (remarks of Professor Braucher); see also Eisenberg, supra note 26, at 663 (The Second Restatement "dramatically broke[] away from the axiomatic school in this area and ... adopted a sweeping new rule" for promises based on past benefit.).

110 E. Allan Farnsworth replaced Braucher as reporter in 1971, when the latter was appointed to the Supreme Judicial Court of Massachusetts.

1111965 Proceedings, supra note 26, at 273-74.

112 Id. at 274. 
tion or moral obligation as consideration; and yet when this case came along the case was decided for the plaintiff . . . and I would suppose that ... this would be likely to happen in most courts. What you have, really, is a line of distinction between essentially gratuitous transactions and cases which are on the borderline of quasi-contracts, where promise removes the difficulty which otherwise would bar quasi-contractual rehef. ${ }^{113}$

This restitutionary explanation of the cases is einbodied in Section 86 of the Second Restatement of Contracts, which provides that "[a] promise made in recognition of a benefit previously received by the promisor froin the promisee is bimding to the extent necessary to prevent mjustice," but that such a promise is not bimding to the extent that the value of the promise is disproportionate to the antecedent benefit. ${ }^{114}$ The comments explain that recovery is based on the proinisor's underlymg obligation to inake restitution for unjust enrichment at the expense of the promisee. ${ }^{115}$ Although restitution is often demed to guard against false, stale or previously hitigated claims, "a subsequent promise to make restitution [may remove] the reason for the demal of relief, and the policy agamst unjust enrichment then prevails."116 Furtliermore, "[e]nforcement of the subsequent promise sometimes makes it unnecessary to decide a difficult question as to the himits on quasi-contractual relief."117

Recent commentary lias accepted and elaborated upon the Second Restatement's restitutionary approach to the moral obligation cases. ${ }^{118}$ For exainple, as part of a larger reconceptualization of con-

113 Id.

114 Section 86, entitled "Promise for Benefit Received," reads in full:

(1) A promise inade in recognition of a benefit previously received by the promisor from the promisee is binding to the extent necessary to prevent injustice.

(2) A promise is not binding under Subsection (1)

(a) if the promisee conferred the benefit as a gift or for other reasons the promisor has not been unjustly enriched; or

(b) to the extent that its value is disproportionate to the benefit.

Restatement (Second) of Contracts $\S 86$ (1979).

115 Id. $\$ 86$ cints. b, c.

116 Id. $\$ 86$ cint. $b$.

117 Id.

118 See sources cited supra note 26; see also Calamari \& Perillo, supra note 22, § 5-4, at 253 (reasoning that the inoral obligation cases are on the "outer fringes of the law of quasi contract"); Murray, supra note 26, $\S 67$, at 298 (commending the Restatement's inaterial benefit rule); Braucher, supra note 26, at 605 (arguing that the Restatement "seeks to draw a distinction between the cases involving moral obligations based on gratitude or sentiment and 
tract law, Professor Melvin Eisenberg has rejected the view, "grounded on the bargain theory of consideration," that promises based on benefit previously conferred are unenforceable. ${ }^{119} \mathrm{He}$ considers the question in the context of the relationship between $A$ and $B$ where $A$ has suffered a loss in rescuing $B$.

$A$ has conferred a benefit on $B$, and $B$ is morally obliged to make compensation. Presumably, therefore, $[B$ is not legally obliged to compensate $A$ ] only because it is deemed desirable to protect persons against liability for benefits that they miglit have declined to accept and pay for if given the clioice, and because of the severe difficulty in many sucli cases of ineasuring the value of the benefit to $B$. A later promise to make compensation invariably removes the first obstacle and normally removes the second. Sucli a promise sliould therefore be enforceable - or, perhaps more precisely, sliould render the promisor liable to make compensation. ${ }^{120}$

those cases which are on the border of quasi-contract or unjust enrichment, where the subsequent promise removes an objection which might otherwise bar quasi-contractual rehef"); Landes \& Posner, supra note 26, at 116 ("The objection to restitution in rescue cases . . . is that the courts should not try to write contracts for people who have failed to agree on terms; if the necessary terms are supphed by the rescue victim's promise, this objection disappears.").

Another explanation of the moral obligation cases suggests that courts enforce subsequent promises only when they are made in recognition of a benefit previously conferred in a defective exchange. See Goetz \& Scott, supra note 26, at 1310-12; James D. Gordon III, Consideration and the Commercial-Gift Dichotomy, 44 Vand. L. Rev. 283, 302-05 (1991); W. Jack Grosse, Moral Obhigation as Consideration in Contracts, 17 Vill. L. Rev. 1 (1971); Henderson, supra note 24 , at $1127,1158-60$. The enforcement of promises on the basis of the promisec's rehance las also been explained as grounded in the enforcement of defective exchanges or the furtherance of economic activity. See Daniel A. Farber \& John H. Matheson, Beyond Promissory Estoppel: Contract Law and the "Invisible Handshake," 52 U. Chi. L. Rev. 903 (1985); Goetz \& Scott, supra note 26, at 1305-09. But see Yorio \& Thel, supra note 16 , at 114-15 (arguing that such courts base enforcement on the importance of the promise itself).

Modern explanations of contract law in terms of exchange typically go beyond the bargain theory of consideration by focusing quite explicitly on the allocative efficiency of exchanges and the relative sterility of nonexchange promises. See Goetz \& Scott, supra note 26 (collecting the literature). This focus permits a more nuanced complexity than did the bargain theory, but it retains important and sometimes unappreciated connections with the bargain theory: all of contract law is still tied to bargaim, albeit more loosely and with bargain more broadly defined. But see Farber \& Matheson, supra, at 946 n.140 (reserving judgment on past consideration cases).

119 Eisenberg, supra note 26, at 663.

120 Id. (citation omitted). 
Eisenberg would have courts recognize more exphcitly the tight link between the question of which promises to enforce and the question of the extent of enforcement. ${ }^{121}$ Because in his view the basis of recovery in these cases is benefit conferred, ${ }^{122}$ he suggests that "the promisee's recovery should ordinarily be himited to the lower of (1) the amount promised or (2) compensation that is fair in light of the underlying obligation, the value of the benefit, and the promisee's cost."123

Eisenberg's explanation reflects prevailing theory, the gist of which is that promises made in recognition of moral obligation are legally significant when they remove obstacles to restitutionary relief. This explanation is surprisingly close to the antecedent-bargam approach advocated by Williston. ${ }^{124}$ Like Williston, adherents of the restitutionary explanation fail (or refuse) to recognize promise as the basis of recovery. Instead, they assume that courts base recovery on something that happened in the past, with the promise serving only to overcome one or another legal obstacle to recovery on that basis.

121 Id. at 640.

122 Eisenberg refines the conventional explanation of the moral obligation cases by focusing on enrichment-as opposed to unjust enrichment. This refinement explains the rescue cases better and also distinguishes the substantive law of restitution, which focuses on unjust enrichment. Eisenberg sees nothing unjust in needing to be rescued, and he points out that, in any event, recovery is usually allowed even without a subsequent promise when there is unjust enrichment. According to Eisenberg, the operative question is simply whether the promisor, when she makes her promise, is morally obliged to compensate tlie promisee for a benefit previously conferred. Id. at 664 .

123 Id. at 664 ; see also id. at 664 n.73 (questioning whether the Second Restateinent goes far enough in limiting the remedy to benefit conferred).

Professor Stanley Henderson has presented the most elaborate restitutionary explanation of the past consideration cases. See Henderson, supra note 24 . Henderson canvasses the cases and statutes and concludes that the underlying principle is that moral-obligation promises trigger enforcement of antecedent restitutionary obligations. Id. at 1183-84.

Professors Charles Goetz and Robert Scott offer a similar explanation in the context of a broader discussion of contract remedies:

Conferral of benefits on the promisor by the promisee prior to a nonreciprocal promise may affect the decision whether to enforce the subsequent promise. Discussion of the enforceability of the subsequent promise implies that the original conferral of benefits was not sufficient to support restitution for unjust enrichment. The subsequent promise may, however, fill the interstices between contract and quasi-contract by minimizing the prospect of reward for forcible imposition of 'benefits.' By removing these objections to a quasi-contractual liability, the subsequent promise justifies recovery of the conferred benefits.

Goetz \& Scott, supra note 26, at 1310.

124 See supra notes 74-84 and accompanying text. 
Mills and Webb, the two cases that dominate the discussion and analysis of past consideration, can be reconciled by a theory based on restitution. Seth Wyman's promise im Mills was legally inconsequential because the promisee, Mills, had no claim to restitutionary relief-flawed or otherwise. Mills conferred a benefit on Levi Wyman, not on his father Seth, who made the promise. Because Seth had not been enriched, Mills could not recover from Seth under a restitutionary theory, notwithstanding Levi's subsequent promise.

The underlymg moral obligation in $W e b b$, in contrast, did rest on a benefit received by the promisor if, as alleged, Webb had saved McGowin's life and was injured in doing so. Nonetheless, Webb would have faced many problems had he asserted a claim for restitutionary rehef. Among other things, he would have had to prove that he in fact prevented an imjury and what the injury would have been. ${ }^{125}$

125 Another common issue in restitution is the measure of recovery. The Second Restatement of Contracts suggests that recovery on the subsequent promise should be limited to the amount of the benefit. Restatement (Second) of Contracts $\$ 86 \mathrm{cmt}$. i (1979); see also Murray, supra note $26, \S 67$, at 297-98 (suggesting that a promise should be enforced if the benefit received is substantial and the promise is not excessive). Professor Eisenberg suggests that recovery might properly be further himited in light of the promisee's costs. Eisenberg, supra note 26, at 664 . Certainly had Webb not been grievously injured in saving McGowin, his clain would not have seeined as compelling as it does. Cf. Restatement (Second) of Restitution $\S 1$ (Tent. Draft No. 1, 1983) ("A person who receives a benefit by reason of an infringement of another person's interest, or of loss suffered by the other, owes restitution ...."); id. $\S 3 \mathrm{cmt}$. c (noting the importance of costs incurred in conferring a benefit through a justifiable response to an exigency); Restatement of Restitution, General Scope Note, at 1 (1936) ("The Restateinent of this Subject deals with situations in which one person is accountable to another on the ground that otherwise he would unjustly benefit or the other would unjustly suffer loss."); id. $\S 1 \mathrm{cmt}$. e (recovery where benefit and loss do not coincide); Landes \& Posner, supra note 26, at 101-05 (justifying salvage awards in excess of salvor's expenses on efficiency grounds); Levmore, supra note 26, at 901-02 (emphasizing rescuers' costs). But cf. Restatement (Second) of Contracts $\$ 86 \mathrm{cmt}$. i \& reporter's note (1979) (citing $W e b b$ as a ease in which "the value of the benefit is uncertain . . . [but] a promise to pay a liquidated sum may serve to fix the amount due if in all the circumstances it is not disproportionate to the benefit.").

Perhaps plaintiffs cannot make out a case for restitutionary recovery if they are not out anything in conferring benefit. Eisenberg's position on the remedy issue where the rescuer's loss is less than the beneficiary's gain, supra note 122, may be more consistent with restitutionary recovery in some cases. For example, when a physician acts in an emergency, the patient is compelled to pay reasonable fees, not the value of the life or limb the physician saved. See Restatement of Restitution $\S 155(1)$ (1937); id. $\S 155 \mathrm{cmt}$. d (physician's recovery).

A promise by the putative recipient of a benefit inay substitute for the promisee's proof on other matters or estop the recipient from asserting other defenses. The significance of a subsequent pronise in obviating defects in the promisee's claim for restitution presumably varies with the terns of the promise and the particulars of the promisee's claim. For example, 
The restitutionary argument is that McGowin's subsequent promise obviated the need for this proof, because by his promise McGowin recognized the conferral of a benefit and specified its value. If Webb had sought restitution directly, he would also have had to prove that he had not acted officiously in conferring a benefit upon McGowin. ${ }^{126}$ Webb's acceptance of payments might show that he did not confer his services gratuitously, thus defeating the presumption of gratuity. ${ }^{127}$

\section{Criticism of the Traditional Approaches}

Restitution then may reconcile Mills and $W e b b,{ }^{128}$ but promise offers an equally, and perhaps inore, plausible reconciliation of these

McGowin's postpromise arguments on the value of benefit might seem less relevant than Seth Wyman's. McGowin acknowledged that he was saved from serious physical injury, set out exactly what he would pay-fifteen dollars every two weeks-and paid it for several years. By contrast, Seth Wyman, so far as appears in the opinion, did not liquidate his obligation by his promise, and he never made any payments. See Restatement (Second) of Contracts $\S 86 \mathrm{cmt}$. d (1979) (proinise shiftimg burden of proof of gratuity). See generally Joseph M. Perillo, Restitution in a Contractual Context, 73 Colum. L. Rev. 1208 (1973) (discussing restitution in a quasi-contractual context).

126 Restatement of Restitution $\S 2$ (1937) ("A person who officiously confers a benefit upon another is not entitled to restitution therefor."); see also Restatement (Second) of Restitution $\S 2$ (Tent. Draft No. 1, 1983) (denying restitution for benefits officiously conferred); John W. Wade, Restitution for Benefits Conferred Without Request, 19 Vand. L. Rev. 1183, I183-86, 1190-94 (1966) (arguing that restitution is demed if the plaintiff intended to act gratuitously).

127 Albert, supra note 26, at 97-98; Goetz \& Scott, supra note 26, at 1310; Henderson, supra note 24, at 1154-59, 1165-76; see also Note, Promissory Obligations Based on Past Benefits or Other Moral Consideration, 7 U. Chi. L. Rev. 124, 129 (1939) (allowing acceptance of promise as corroboration of nongratuitous intention).

The restitutionary theory of $W e b b$ is that McGowin's promise estopped his estate from asserting defenses to Webb's claim for restitution. However, the courts were not prepared to allow Webb to use the promise to estop the estate from asserting defenses. Although the result in $W e b b$ is sometimes said to be that Webb recovered, see, e.g., Sharp, supra note 26, at 789, the appellate courts did not allow Webb to enforce the promise against McGowin's estate. Instead, the courts reversed a nonsuit and remanded the case for trial. Accordingly, $W e b b$ is not a case that can be cited for the proposition that the subsequent promise serves to satisfy objections to restitutionary relief.

128 The Second Restatement seeins to reconcile the cases on this basis, stating that promises "made in recognition of a benefit previously rcceived by the promisor" are binding. Restatement (Second) of Contracts $\S 86(1)$ (1979) (emphasis supplied); see also Farnsworth, supra note $22, \S 2.8$, at 60 (discussing the requirement that benefit be rcceived by the promisor). Compare Restatement (Second) of Contracts, supra, $\S 86$ illus. 1 (based on Mills) with id. illns. $6 \& 7$ (based on Boothe v. Fitzpatrick, 36 Vt. 681 (1864) (promisee found and cared for promisor's lost bull), and on $W e b b$ ). There is rcason to doubt, however, that restitution really distinguishes the cases. See infra text accompanying notes 152-53 (suggesting that the court would have enforced McGowin's promise even if his son's life had been saved rather than his own). 
famous cases. ${ }^{129}$ The cases may simply show that courts are willing to enforce serious, well-considered promises, but not rash and ill-considered promises. ${ }^{130}$ Under this promise-based standard, the promise im $W e b b$ is much more deserving of enforcement than the promise $\mathrm{m}$ Mills. Webb had twenty-eight days to reflect before making his promise; Wyman made his prolmise only four days after being informed that Mills cared for his dying son. ${ }^{131}$ Thus, the proimse im Mills was more likely a response to a fleeting emotion of gratitude than the proimse in $W e b b$. Subsequent events support this reading. Wyinan himself repudiated his proimse; ${ }^{132}$ McGowin, in contrast, performed in accordance with his promise for over eight years, with the legal dispute arismg only after his executors repudiated. ${ }^{133}$ Performance by the promisor, particularly over a long period, confirms that the promise was well-considered. In addition, McGowin had more powerful reasons for making a serious prolmse than did Wyınan: McGowin derived substantial benefit and Webb incurred substantial detriment from the underlying act if the allegations of Webb's complaint were true. In contrast, Wyman derived little benefit from Mills' care for liis son-the son died anyway-and Mills suffered minimal detriment-merely the cost and time of treatment. These facts justify the conclusion that the promise in Webb was more serious and well-considered tlıan tlıe promise in Mills. ${ }^{134}$ Thus, a theory based on promise reconciles tliese cases as well.

129 We will argue in the next Part that restitutionary theory cannot explain many moral obligation cases. See infra Part II.A.

130 See generally Yorio \& Thel, supra note 16, at $124-27$ (making this argument in the context of Section 90).

131 See Webb v. McGowin, 168 So. 196, 196-97 (Ala. Ct. App. 1935), cert. denied with opimion, 168 So. 199 (Ala. 1936); Mills v. Wyman, 20 Mass. (3 Pick.) 207, 207 (1825).

132 Mills, 20 Mass. (3 Pick.) at 209.

$133 W e b b, 168$ So. at 197 . Cf. Levmore, supra note 26 , at 901 (observing that recovery is more likely when the promisor's estate breaches and suggesting that the issue may be more a matter of estate law than contract).

134 Harrington v. Taylor, 36 S.E.2d 227 (N.C. 1945), involved facts somewhat similar to $W e b b$. The plaintiff's hand was severely mutilated in the process of saving the defendant's life. The defendant subsequently promised to pay the plaintiff her damages. After paying a small sum, the defendant reneged on his promise. The court held that the promise, lacking consideration, was unenforceable.

$W e b b$ and Harrington may not be meaningfully reconcilable at all. Certainly they cannot be distinguished on restitutionary grounds. In both cases, the promisor received a substantial benefit from the plaintiff and the plaintiff suffered in doing good. The distinctions between the cases, if there are any, relate to the nature of the promisor's commitment. In Harrington, the 
In light of Fuller's promissory explanation of $W e b b,{ }^{135}$ it is ironic that the nodern restitutionary approach seenis to echo Fuller's earlier work, The Reliance Interest in Contract Damages, ${ }^{136}$ in which Fuller and Perdue set out three interests of tlie promisee in contract reniedies, includinig the promisee's restitution niterest. ${ }^{137}$ However, the restitution interest that Fuller and Perdue identified is very different fron the one conventionally thought to be at issue in the inoral obhgation cases. For Fuller and Perdue, the restitution niterest was the promisee's right to recover any value that she conferred on the pron1isor in reliance on the promise. ${ }^{138}$ This interest is tied to the pron1isee's reliance on the pronise, ${ }^{139}$ and is but a subset of the reliance niterest. ${ }^{140}$ This restitution interest cannot explain tlie nioral obligation cases. Whereas Fuller and Perdue defined the restitution interest in terms of benefits conferred by the promisee after the promise was inade and in retiance thereon, the benefit at issue in the inoral obligation cases is one conferred prior to the niaking of the promise and thus not in rehiance on the promise. ${ }^{141}$

The reason modern commentators interpret the nioral obligation cases in terms of restitution inay lie in anotlier facet of the Fuller and

defendant apparently repudiated soon after making the promise and after paying only a small sum on the promise. Thus, the promise in Harrington was probably less well-considered than the promise in Webb. Moreover, the promisor never repudiated in $W e b b$, whereas he did in Harrington. See Levmore, supra note 26, at 901-02.

135 See supra text accompanying notes 98-102.

136 Fuller \& Perdue, supra note 11.

137 Id. at 53-54; see supra notes 20-23, 25 and accompanying text.

138 Fuller \& Perdue, supra note 11, at 53-54.

139 Id. at 53; see also id. at 54 ("the restitution interest umites two elements: (1) rehance by the promisee, (2) a resnltant gain to the promisor.").

140 Id. at 53-54, 71-72; see Robert Childres \& Jack Garamella, The Law of Restitution and the Rehance Interest in Contract, 64 Nw. U.L. Rev. 433, 436 passim (1969) (arguing that the First Restatement of Contracts fails to distinguish those cases that are cloaked in restitutionary terms but are factually based on reliance).

141 Fuller and Perdue's concern with rehance has also been overlooked in other statements of the restitution interest. The Second Restatement introduces the subject of remedies with the statement that the purpose of contract remedies is to protect the expectation, reliance, or restitution interests of promisees. See Restatement (Second) of Contracts $\$ 344$ (1979). This statement and list are based on Fuller and Perdue's work. See id. reporter's note; E. Allan Farnsworth, Some Prefatory Remarks: From Rules to Standards, 67 Cornell L. Rev. 634, 635 (1982) (acknowledging influence of Fuller and Perdue on $\S 344$ ). Interestingly, however, the Restatement defines the restitution interest by reference to benefits the promisee has conferred on the promisor, without limitation to benefits conferred in reliance on the promise. See Restatement (Second) of Contracts § 344(c) (1979). 
Perdue article: its almost exclusive concern with promisees and their interests in having promises kept. ${ }^{142}$ The promisee's compelling claim in the inoral obligation cases is to be coinpensated for the harm that she suffered or the benefit that she conferred on the promisor, in either event before the promise was inade. If the interests of the promisee are all that matters, the reinedy for breach of promises supported by past consideration inust be grounded in the harm suffered or the benefit conferred by the promisee before the promise was made. But as Fuller suggested in 1941 and as we argue below, the inoral obligation cases can be explained on the basis of promise, as opposed to restitution, if the focus shifts to the promisor.

Although Mills and Webb may be reconciled under either a restitutionary or promissory theory, the rest of this Article shows that restitution and promise often lead to different conclusions about which promises based on moral obligation are enforceable and about what relief is appropriate to remedy breach of those promises. In addition, Part II disputes the argument inade by the Second Restatement and modern commentators that promises matter only because they remove impediments to enforcing inoral obligations. We offer instead a promise-based theory, under which a powerful underlymg inoral obligation justifies enforcing promises, the legal obligation is defined by the promise, and a promise is a condition for judicial intervention.

\section{Moral Obligation and Promise}

It is difficult to predict just when courts will enforce a promise made in recognition of felt inoral obligation, and this Article does not offer a rule that predicts when courts will intervene. ${ }^{143}$ Nonetheless, by studying the way courts respond to typical situations, it is possible to improve our appreciation of what courts do and what inoves thein to act. Toward that end, this Part examines three aspects of the inoral obligation cases: the nature of the underlying inoral obhigations that suffice to trigger judicial action on promises; the remedy for breacli of tliose proimses; and tlie requirement of a promise. When the cases are

142 See Yorio \& Thel, supra note 16, at 119-21; see also supra notes 20-23 and accompanying text (discussing inappropriateness of expeetancy damages when focus is on promisee).

143 We do show that once courts determme that a moral obligation is sufficient to justify judicial action on a subsequent promise, they consistently act according to easily articulated rules about promise and remedy. See infra parts II.B-C. 
examined from the perspective of promise, similarities that have generally been overlooked become apparent. This is not to say that insights cannot be gained by looking at the cases in other ways. For instance, those who have explored the inoral obligation cases from the perspective of restitution have shown the power of the judicial imipulse to protect those who have conferred substantial benefit on others without gratuitous intent. However, the judicial impulse to enforce promises is also powerful, and the cases cannot be understood without recognizing it.

\section{A. Operative Moral Obligations}

In analyzimg moral obligation cases, courts and commentators alike have focused on identifying what sorts of underlying moral obhgation will make a subsequent promise legally binding - that is, which sucl obligations are operative. Indeed, the preoccupation with identifying sufficient moral obligation has caused most of the shortcomings in the conventional wisdom. Commentators seem to presume that the only thing courts are concerned with in these cases is the underlying obhgation; that once courts find that the obhigation underlymg a promise is sufficient to justify judicial intervention, they respond to that obhigation rather than to the subsequent promise. ${ }^{144}$ The thesis of this Article, in contrast, is that a judicial finding of sufficient moral obhigation serves instead inerely as a trigger for enforcing the subsequent proinise. Whichever view is correct, however, it is clear that courts will not act at all on a promise inade in recognition of a felt moral obligation unless they find that obhigation compelling. Accordingly, before turning to the way courts respond to promises made in recognition of moral obhigation, we examine the preliminary question of sufficient moral obligation.

As outlined in Part $I$, the conventional wisdom is that a promise motivated by felt moral obligation will be enforced when the obligation is restitutionary; that is, when the promisor made tlie promise because he previously received a benefit from the promisee and justice requires that he compensate her. Unjust enrichment, or at least enrichment, ${ }^{145}$ is present im most of the situations in which moral obli-

144 See infra note 188 and accompanying text.

145 Professor Eisenberg suggests that "unjustness" is not required, but that the test is whether the promisor, "at the time he made his promise, ... [was] morally obliged, by reason 
gation is conventionally said to make promises enforceable: promises to pay debts barred by operation of law and promises like that in the paradigmatic moral obligation case, Webb v. McGowin. ${ }^{146}$ Furthermore, unjust enrichment makes a powerful call for societal imtervention, and judges are probably sufficiently familiar with the concept of restitution to be comfortable about enforcing promises based on restitutionary obligations. ${ }^{147}$ Sometimes principles of restitution alone miglit justify enforcing a promise to compensate a person who lias previously conferred a benefit on the promisor. However, the regular enforceinent of promises to make restitution does not establish that courts are moved by restitution when they enforce tliose promises; the imperative of the promisor's commitınent miglit itself justify enforcement.

When a court enforces a promise to do exactly wliat restitution obliges the promisor to do anyway, it is hard to gauge the legal significance of commitinent or restitution. The telling cases are those in which the calls of promise and restitution diverge. There are inany sucli cases, and liere we discuss those in whicli courts enforce promises made in recogmition of a felt moral obligation to do somethimg otlier tlian inake restitution. ${ }^{148}$ If courts were interested in promises based on moral obligation only when tliose promises gave tliem a way to redress unjust enrichment, then presumably enricliment would be a condition of recovery. Yet courts often enforce promises based on moral obligation even tliough the promisor has not been enriclied.

Consider, for example, anotlier well-known case, Medberry v. Olcovich, ${ }^{149}$ in which the court enforced a promise made in recognition of moral obligation even tliougli the proinisor liad not been enriclied at all. Medberry's son was injured in an automobile driven by Olco-

of a past benefit conferred, to make some compensation to" the promisee. Eisenberg, supra note 26, at 664; see also supra note 122 (discussing Eisenberg's argument).

146168 So. 196 (Ala. Ct. App. 1935), cert deried with opinion, 168 So. 199 (Ala. 1936); see discussion supra Part I.C.

147 The first section of the Restatement of Restitution states, without qualification, that "[a] person who has been unjustly enriched at the expense of another is required to make restitution to the other." Restatement of Restitution \$ 1 (1937).

148 In Part II.B we discuss cases enforcing promises to do more or less than restitution requires, and in Part II.C we discuss cases refusing to enforce moral obligation in the absence of a promise.

14959 P.2d 551 (Cal. Dist. Ct. App.), petition denied, 60 P.2d 281 (Cal. 1936). 
vich's son. Medberry testified that Olcovich told him, "we are sorry that this thing has happened, but you have whatever done is necessary to get the boy fixed up, and I will stand any reasonable expense."150 Olcovich subsequently paid some of the boy's medical expenses, but after he refused to pay the rest Medberry sued on his promise. The trial court held that Olcovich was not liable because the promise was without consideration. The court of appeals reversed and directed that judgment be entered for the reasonable value of the boy's medical expenses.

The court recognized that Olcovich was not responsible for the accident and was free to refuse to assist Medberry's son. Olcovich knew, however, that the boy needed medical care and that his father's resources were madequate to provide it. Moreover, the court emphasized that Olcovich paid some of the expenses of care, in conformity with his promise. Under the circumstances, the court concluded,

it seems to us there was some moral obligation resting on ... Olcovich, predicated on his promise, to furnish to the minor plaintiff such assistance and care as were necessary to reheve the latter's suffering. This obligation is shown by the evidence to have been recognized from the start, was partially executed by him, and, in our opinion, should be held to constitute a sufficient consideration for the legal obligation resting thereon. . . . Emil Olcovich ought not now therefore, after the services have been rendered and the expenses incurred in rehance upon his promise, and after he has made partial payments pursuant to his promise, be permitted to repudiate it. . . ${ }^{151}$

Consider also what would have happened if Webb had saved McGowin's adult child instead of McGowin. McGowin would not have received a benefit, and, accordingly, would not have had any restitutionary obhigation. The Second Restatement of Contracts sug-

150 Id. at 554-55.

151 Id. at 555. The Supreme Court of California denied a hearing on the appeal, declaring that the judgment of the court of appeals was proper, "even though it may be assumed to be based upon the conclusion, among others, that the agreement was sufficiently supported by a moral obligation." 60 P.2d 281, 282 (Cal. 1936). The supreme court may have affirmed on a theory of promissory estoppel, inasmuch as it noted that the plaintiffs "suffered prejudice by reason of the expenses incurred by them on the promise of the defendant. ... Under such circumstances, a sufficient legal consideration for the promise was present." Id. However, the supreme court also cited the California statute that declares moral obligation to be consideration, Cal. Civ. Code $\S 1606$ (West 1982), which, interestingly, the court of appeals did not cite. Id. 
gests that McGowin would not have been legally bound by a promise in this situation, for its rule is that a promise is binding when the promisor has himself received a benefit. ${ }^{152}$ Yet it is hard to beheve that any court prepared to allow Webb to recover on McGowin's promise would have reached a different result if Webb had been injured saving McGowin's child. ${ }^{153}$

Cases like Medberry and $W e b b$ are unusual, but courts often face promises based on moral obligation without unjust enrichment when fathers promise to support their children born out of wedlock. Surely fathers have a moral obligation to support their nonmarital minor children. ${ }^{154}$ But a father's promise to provide support, inade in recognition of his obligation and not in return for anything froin the child, lacks consideration as that term is conventionally defined. Many courts, finding lack of consideration to be an insurmountable barrier, have refused to enforce promises to provide support, despite the power of the father's moral obligation. ${ }^{155}$ Other courts have been, in Corbin's phrase, "astute to find soine sufficient consideration . . .."156 Still others have simply enforced the promises without imsisting upon

152 Restatement (Second) of Contracts $\$ 86(1)$ (1979); see supra notes $114-15$ and accompanying text.

153 See Gilmore, supra note 26, at 75 ("Are we to believe that my promise to pay the stranger who takes care of my bull is binding but that my promise to pay the stranger who takes care of my dying son is not?'); see also Lon Fuller \& Melvin A. Eisenberg, Basic Contract Law 166 (4th ed. 1981) (asking whether the stated rationale of the Second Restatement is consistent with the result in Mills).

The requirement that the promisor have benefited may superficially square the grant of recovery in Webb with the demial in Mills, although there is hittle reason to think the result would have been different in Mills if Wyinan père had himself received the benefit of Mills' ministrations. The court suggested that if Mills wanted to recover on a nonpromissory theory, he had to proceed on that theory directly. See Mills v. Wyman, 20 Mass. (3 Pick.) 207, 212 (1825) (discussing Wyman's statutory obhigation to support his poor relatives).

154 Nonetheless, there is generally no legal obhgation of support under the common law. See infra notes 163-64 and accompanying text.

155 See, e.g., Stevens v. Niblack's Adm'r. 75 S.W.2d 770, 771 (Ky. 1934); C. v. W., 480 S.W.2d 474, 478 (Tex. Civ. App. 1972). See generally 1 A Corbin, supra note 27, $\S 231$, at 347 (stating that moral obligation is insufficient when no legal obligation to provide support exists); Annotation, Validity and Construction of Putative Father's Promise to Support or Provide for Illegitimate Child, 20 A.L.R.3d 500, $\S 9$ (c) (1968) (collecting cases).

156 A Corbin, supra note 27, $\S 231$, at 347-48; see, e.g., Schumm v. Berg, 231 P.2d 39, 4446 (Cal. 1951) (finding that mother's promise to name child after father was consideration for support); Todd v. Weber, 95 N.Y. 181, 189 (1884) (deciding that natural obligation of father to child will uphold contract); Hicks v. Gregory, 137 Eng. Rep. 556, 558-59 (1849) (finding that mother's behaving well and raising child properly was consideration for father's promise of support); Ingalls Shipbuilding Corp. v. Neuman, 322 F. Supp. 1229, 1244 (S.D. Miss. 1970) 
consideration, apparently finding that the power of the moral obligation demands enforceinent of the promise at least as much as bargained-for consideration ever could. ${ }^{157}$

This spirit is illustrated by the forceful opinion of the Supreine Court of Georgia in Hargroves v. Freeman. ${ }^{158}$ The issue was whether a nonmarital child could enforce his father's promissory note for $\$ 1,000$. The father's estate argued that the trial court erred in refusing to charge the jury that there could be no recovery if "the ouly consideration for the note was to provide for and support" the child. ${ }^{159}$ In holding the note enforceable, the court volunteered that the child's mother had probably given consideration for the note, but declined to base its decision on that ground. ${ }^{160}$ Instead, the court held that the father's inoral and legal obhigation to support the child inade his note enforceable, grounding the decision in the "old doctrine ... that a moral obligation was alone a sufficient consideration to support an express promise."161 The tenor of inany of the moral obhigation cases is captured in the reason the court gave for enforcing the proinise: " 'Where a man is bound in honor and conscience,' and I will add,

(holding that weekly support payments in exchange for care of children created a binding agreeinent).

157 See, e.g., Franklin v. Congelosi, 273 A.2d 291, 293 (Conn. Cir. Ct. 1970); Thorpe v. Collins, 263 S.E.2d 115, 118 (Ga. 1980); Gray v. Plummer, 73 S.E.2d 569, 571 (Ga. Ct. App. 1952); Trayer v. Setzer, 101 N.W. 989, 990 (Neb. 1904); Smazal v. Dassow, 127 N.W.2d 234, 238 (Wis. 1964) (dissent) (complaint stated a cause of action notwithstanding exclusive statutory vehicle for settlements of paternity actions, because there was no return promise to forebear from instituting paternity proceedings); Hicks v. Gregory, 137 Eng. Rep. 556, 559 (1849) (Williams, J., concurring) ("I am extremely glad that the lord chief justice and my brother Maule have coine to the conclusion that the promise was founded upon an adequate legal consideration; for, I must confess that my own inpression is, that the testator merely mtended to confer upon the plaintiff a bounty which he might reeall at pleasure . . ."); 2 James Kent, Commentaries on American Law *215 \& n.b ("The father of a bastard child is liable upon his implied contract, for its necessary inaintenance .... But except in such a special case [e.g., adoption], the putative father is not liable except upon an express promise, or upon an order of filiation under the statute.").

$15812 \mathrm{Ga} .342$ (1852).

159 Id. at 344.

160 Id. at 348-49.

161 Id. at 344. The opinion quoted extensively from cases enforcing pronises to do what a man "in honor and conscience" ought to do. See, e.g., id. at 344-45 (quoting Turner v. Vaughn, 95 Eng. Rep. 845 (1767)). 
in law, too, 'God forbid that a Court of Law should say the contrary." "162

The reason a father's promise to support his child is enforceable is not that it perfects the child's right to restitution. A child does not by her mere existence confer legally cognizable benefit on her father and, therefore, she has no restitutionary claim. ${ }^{163}$ Although one might expect courts to require fathers to support their children-even im the absence of promise, benefit conferred, or statute-fathers generally did not have any obhigation to support their nonmarital children when many of these cases were decided. ${ }^{164}$ When a father promises to support his child, his compelling moral obligation to provide support, rather than the child's restitutionary interest, has led courts to enforce the promise.

Charitable subscriptions are another group of promises that are powerful because the promisor makes a commitinent to do what she recognizes that she ought to do. ${ }^{165}$ Not surprisingly, courts regularly enforce promises to give to charities, even though a charitable subscription "seeins the archetype of the unenforceable gratuitous promise."166 Courts at one time justified enforcement of subscriptions by

162 Id. at 349 (quoting Turner v. Vaughn, 95 Eng. Rep. 845 (1767)). Hargroves was later codified in Georgia. The statute obligating fatliers to support their nonmarital clildren was amended to provide that the statutory obligation of support "shall be good consideration to support a contract ...." Thorpe v. Collins, 263 S.E.2d 115, 118 n.2 (Ga. 1980) (quoting Ga. Code Ann. \$ 74-202, which lias since been amended).

163 One miglit argue that fatlers do benefit by having children, but the coinmon law did not recognize any benefit sufficient to support a paternal duty of support. See Annotation, supra note $155, \S 2$.

164 The coinmon law did not require fathers to support their nonmarital clildren. See Thorpe v. Collins, 263 S.E.2d 115, 118 (Ga. 1980); C. v. W., 480 S.W.2d 474, 477 (Tex. Civ. App. 1972); Todd v. Weber, 95 N.Y. 181, 189 (1884). Statutes in most states now require fathers to support their children born out of wedlock. See Annotation, supra note 155, § 2. Where such statutes govern, most promises of support are likely to be supported by bargainedfor consideration, because fatlers are likely to exact consideration in the form of a tacit or explicit promise to forgo support proceedings in return for their promises. See id. $\S \S 2$ (b), 16(a); see also Sinazal v. Dassow, 127 N.W.2d 234, 237 (Wis. 1964) (stating that statutory proceedings are the exclusive vehicle for creating legally enforceable support agreenents).

165 Robert Scott lias also noted the resemblance between charitable subscriptions and prounises based on inoral obligation. Robert E. Scott, Error and Rationality in Individual Decisioninaking: An Essay on the Relationship Between Cognitive Illusions and the Managenent of Choices, 59 S. Cal. L. Rev. 329, 360 n. 109 (1986).

166 Farnsworth, supra note 22, $\S 2.19$, at 93 . 
stretching to find consideration ${ }^{167}$ or reliance, ${ }^{168}$ but courts now simply declare tliat charitable subscriptions are enforceable. ${ }^{169}$ Partly because courts sometimes explain enforcement of subscriptions in terms of reliance ${ }^{170}$ and partly because of the way the Second Restatement was drafted, ${ }^{171}$ the Second Restatement's rule for cliaritable subscriptions is appended as the second subsection of Section 90, the famous Restatement provision on promissory estoppel. Nevertheless, recognizing that the reliance found in charitable subscription cases is

167 See, e.g., Allegheny College v. National Chautauqua County Bank, 159 N.E. 173, 174 (N.Y. 1927); see also Restatement (Second) of Contracts $\S 90 \mathrm{cmt}$. f (1979) (discussing $\S 90(2)$ 's treatment of charitable subscriptions); 1A Corbin, supra note 27, $\S 198$ (noting the various means by which courts purported to find consideration that did not truly exist); Farnsworth, supra note $22, \S 2.19$, at 94 (stating that the "desire to support private philanthropy ... spawned a variety of tenuous arguments designed to show that such promises were supported by consideration"); 1 Williston II, supra note $64, \S 116$ (discussing the inadequacies of the "consideration" rehed on in such cases); Shattuck, supra note 22, at 932-33 (declaring there to be "an entire absence of orthodox consideration" in charitable subscription cases); Yorio \& Thel, supra note 16, at 163 n.347 (citing other authorities who have concluded that courts often found consideration that in reality did not exist).

168 See, e.g., Allegheny College, 159 N.E. at 174-75; see also Calamari \& Perillo, supra note $22, \S 6-2$, at 280 ("Of late, some courts have . . placed their decisions [im charitable subscription cases] on the grounds of promissory estoppel."); Murray, supra note $26, \S 66$, at 277-78 ("[E]xploration of promises made to charities demonstrated the proclivity of courts to discover ... validation devices, mcluding detrimental reliance, to inake such promises enforceable."); Boyer, supra note 22, at 464-65 ("The most common application of the doctrine of promissory estoppel has been in the charitable subscription cases."); Shattuck, supra note 22, at 933-34 (noting that courts typically grant recovery for the full amount of the subscription, even though actual rehance may be difficult to ineasure); Yorio \& Thel, supra note 16, at 163 n.347 (stating that "rehance theory cannot fully explain the [charitable subscription cases]").

169 See, e.g., Salsbury v. Northwestern Bell Tel. Co., 221 N.W.2d 609, 613 (Iowa 1974); see also Calamari \& Perillo, supra note 22, § 6-2, at 281 (noting that under the Restateinent (Second) "a charitable subscription is enforceable without consideration and without . . . reliance"); Russell G. Donaldson, Annotation, Lack of Consideration as Barring Enforceinent of Promise to Make Charitable Contribution or Subscription, 86 A.L.R.4th 241, 250-52 (1991) (discussing Salsbury and similar cases).

170 See supra note 168; see also Murray, supra note $26, \S 62$, at 240 n.94 ("[T] he famous Allegheny College opinion ... undoubtedly proinpted subsequent courts to use the detrimental reliance device to support charitable subscription promises . . ..").

17 See Yorio \& Thel, supra note 16, at 127-28, 152-54. 
often fictitious, ${ }^{172}$ the Second Restatement states that charitable subscriptions are enforceable without proof of reliance. ${ }^{173}$

Although courts enforce charitable subscriptions im the absence of consideration or reliance, commentators-and indeed courts themselves-liave liad a liard time explaining wlyy. ${ }^{174}$ Courts sometimes say that cliaritable subscriptions are enforced because of public policy, ${ }^{175}$ but public policy cannot explain wliy subscriptions to dubious charities are enforceable wlien promises to do good work are not. Similarly, tlie public policy favoring education that is said to justify enforcmg subscriptions to colleges does not require parents to pay for their cliildren's college education. ${ }^{176}$ The real difference between cliaritable subscriptions and other gratuitous promises is tliat subscriptions are grounded in-and made in recognition of-moral obligation, and tlie cases make more sense considered in tliat liglit.

The moral obligation underlying cliaritable subscriptions is the vague but real sense that those witli the wherewitlial sliould contribute to the improvement of the community. ${ }^{177}$ Courts, if not legislatures, are reluctant to force people to provide for the rest of tlie

172 Professor Braucher, the draftsman of $\$ 90$, admitted that reliance is often fictitious in the charitable subscription cases. See 1965 Proceedings, supra note 26, at 289, 298; see also Restateinent (Second) of Contracts $\S 90 \mathrm{cmt}$. $\mathrm{f}$ (1979) ("Where recovery is based on rehance in such cases, a probability of reliance is enough ....").

173 Restatement (Second) of Contracts $\S 90(2)$ (1979); see also Murray, supra note 26, § 62, at 241 (commending the Restatement for holding charitable subscriptions enforceable despite the absence of reliance). Nor is consideration required for the enforcement of promises covered by $\S 90$. See Restatement (Second) of Contracts $\S 90$ (1979).

174 See Boyer, supra note 22, at 464-65; Yorio \& Thel, supra note 16, at 153-54.

175 See, e.g., Calamari \& Perillo, supra note 22, § 6-2, at 280-81; Farnsworth, supra note 22, $\S 2.19$, at $94-95$.

176 See, e.g., Peterson v. Peterson, 319 N.W.2d 414, 414 (Minn. 1982); see also Chesonis v. Chesonis, 538 A.2d 1376, 1378-79 (Pa. Super. Ct. 1988) (concurring opinion) (arguing that estrangement should be a factor in deeiding obligation to contribute to child's college education). But see Newburgh v. Arrigo, 443 A.2d 1031, 1037-39 (N.J. 1982) (stating that although generally parents need not support children after inajority, they must contribute to college education in soine circuinstances). See generally Robert M. Washburn, Post-Majority Support: Oh Dad, Poor Dad, 44 Temp. L.Q. 319 (1971) (discussing divorced fathers' support obligation to post-minority children); Jay M. Zitter, Annotation, Postsecondary Education as Within Nondivorced Parent's Child-Support Obligation, 42 A.L.R.4th 819 (1985) (collecting and discussing relevant cases); Annotation, Responsibility of Noncustodial Divorced Parent to Pay for, or Contribute to, Costs of Child's College Education, 99 A.L.R.3d 322 (1980) (same).

177 To be sure, some courts may not find the obligation to support charities particularly coinpelling. Cf. $1 \mathrm{~A}$ Corbin, supra note $27, \S 231$, at 345 :

The consensus of community opimion will frequently assert the existence of a moral obligation to divide one's worldly goods with another ... [t]he nearly universal holding 
community. The situation changes, however, when a person promises to support an inistitution that does good work. By her promise, the subscriber acknowledges and embraces her obligation to facilitate good work. This commitment to satisfy a recognized moral obligation distinguislies (enforceable) gratuitous promises to charities from (unenforceable) promises to make gifts to friends or relatives. A court can be reasonably confident that a subscription to a charity is based on the promisor's sense of obligation to the community. ${ }^{178}$ In contrast, a gratuitous promise to a friend or relative may be made in recoguition of an equally compelling obligation, but it may also be niade out of generosity, pity or some otlier less compelling consideration. Courts niay be unwilling to nitervene ni such cases because they are unable to determine that the promisor was, in fact, responding to a conipelling moral obhigation. ${ }^{179}$

Charitable subscriptions and promises conventionally said to be based on past consideration are promises to do wliat the promisor recognizes slie ouglit to do. They have anotlier common characteristic that may be even inore important in explaining their legal treatment: the relationship between inducement and promise. The doctrines that identify the great bulk of enforceable promises both turn on wliat a promise causes to liappen. Consideration screens for and enforces promises that induce tlie promisee to do something for the promisor or for a third party. ${ }^{180}$ Promissory estoppel screens for

is that the existing moral obligation is not a sufficient basis for the enforcement of an express proinise to render the performance that it requires.

This may explain why some courts refuse to enforce charitable subscriptions that are not supported by consideration or rehance. See, e.g., Jordan v. Mount Sinai Hosp., 276 So.2d 102, 108 (Fla. Dist. Ct. App. 1973), aff'd, 290 So.2d 484 (Fla. 1974); Maryland Nat'l Bank v. United Jewish Appeal Fed'n, 407 A.2d 1130, 1138 (Md. 1979); Arrowsmith v. Mercantile-Safe Deposit \& Trust Co., 545 A.2d 674, 683-85 (Md. 1988) (reaffirming Maryland Nat'l Bank).

178 Major donors may give to a charity to increase their power and control over its activities. Cf. William D. Andrews, Personal Deductions in an Ideal Income Tax, $86 \mathrm{Harv}$. L. Rev. 309, 363 (1972) (discussing whether exercise of power over charitable institutions should affect tax treatment of contributions). If so, the pledge resembles a bargain, in which the pledgor gets soinething in return, and slould be enforceable on that basis.

179 Cf. Haviglurst, supra note 65, at 18 (commenting on resemblance between promises proinpted by sense of moral duty and promises motivated by affection).

180 See Farnsworth, supra note $22, \S 2.9$ (test of consideration is promisor's purpose to induce return performance); Murray, supra note $26, \S 61$ (discussing inducement and consideration).

The particular strength of bargain-relative to both promissory estoppel and moral obligation-as a basis for enforcing promise may also be explained by the role of inducement 
and sometimies enforces promises that may mduce the promisee or a third party to act in a particular way. ${ }^{181}$ Although these doctrines focus on what the promise mduces, the doctrine of moral obligation and the charitable subscription cases focus on what induces the promise. ${ }^{182}$ Put in terins of cause and effect, in consideration and promissory estoppel cases, the promise causes some significant act or forbearance, whereas in moral obligation cases the significant act or forbearance causes the promise.

A court will not enforce a promise based on felt inoral obhigation unless it finds the obhigation to be compelling. ${ }^{183}$ Defining the class of sufficient obhigation is difficult. What is clear, however, is that restitutionary obligations are not the only obligations that trigger judicial intervention. Promises to do what the promisor recognizes she ought to do inay be enforced even when the promisor is not responding to the felt obligation to restore a benefit previously received. Restitution's imperative is that those who confer benefit should be compensated, at least when they have not acted officiously. When no benefit has been conferred, there is no such imperative. When courts go beyond restoring benefit to the promisee in enforcing promises made in recognition of moral obhigation, they go beyond the imperative of

in bargain. A bargained-for promise both induces and is induced by the promisee's return performance, the exchanged promises serving, as Holmes put it, as reciprocal inducement for each other. See Holmes, supra note 59, at 293-94.

181 The statement of the doctrine of promissory estoppel in the text is different from the conventional statement, but the text correctly states the law. See Yorio \& Thel, supra note 16, at 113 (arguing that the prospect of reliance can be sufficient to make a promise enforceable). Inducement plays an even more prominent role in the conventional statement of the doctrine, in which actual inducement-as opposed to possible inducement-is necessary. See Restatement (Second) of Contracts § 9O(1) (1979) ("A promise which the promisor should reasonably expect to induce action or forbearance . . . and which does induce such action or forbearance is binding ....") (emphasis added).

182 See $1 \mathrm{~A}$ Corbin, supra note $27, \S 210$, at 275 (past event must induce promise). Whereas the decision to enforce a promise grounded in moral obligation depends on the effect of a past action or an existing situation-im contrast to the future-oriented inquiry of classical consideration and reliance doctrine-the promise itself will typically look to the future. The promisor's commitment is to do soinething in the future, and the promisor's obligation may be conditioned on the promisee's future conduct. A gratuitous promise is not made enforceable by the addition of a condition, however, and a condition is not the same as a bargain. See Farnsworth, supra note $22, \S 2.9$, at 64 (distinguishing condition from bargain).

183 See 1 A Corbin, supra note $27, \S 210$, at 275 ("In our search for the 'past considerations' that are operative ... we need look only among those that are inducing factors, causing promises to be made. Many of these inducing factors are quite imsufficient."). 
restitution. ${ }^{184}$ In the absence of benefit, something other than restitution must be at work.

\section{B. The Promise Defines the Legal Obligation}

The best clue to finding the principles that operate when courts enforce promises based on felt moral obligation may he in the reinedies that courts grant. The reinedy itself is substantial evidence of the principle underlying the remedy, and the consistent award of either restitutionary or promissory remedies in cases in which those reinedies differ would seem to be strong evidence that courts are responding to one principle over the other. ${ }^{185}$ Even if we are not able to discern what motivates judges from observing their actions, the consistent award of one or the other remedy has the effect of advancing a particular principle. If the reinedy in moral obhigation cases were typically equal to the value of the benefit the promisor previously received or were otherwise measured by reference to the underlying obhigation, it would suggest that the operative judicial mipulse is to compel people to he up to their nonpromissory obhigations. ${ }^{186}$ The cases, however, suggest otherwise: courts typically award expectation damages measured by the value of the promise, indicating that the promise is what matters and that the underlying moral obligation is important only as a screen for identifying important promises to enforce. ${ }^{187}$

184 See Restatement of Restitution $\S 1 \mathrm{cmt}$. a (1936) ("A person obtains restitution when he is restored to the position he formerly occupied ....."); see also id., Introductory Note to Ch. 8, Topic 2, at 595 ("Actions for restitution have for their primary purpose taking from the defendant and restoring to the plaintiff ....").

185 See Karl N. Llewellyn, Some Realism about Realism-Responding to Dean Pound, 44 Harv. L. Rev. 1222, 1244 (1931) ("Not only 'no remedy, no right,' but 'precisely as much right as remedy' "); Yorio \& Thel, supra note 16, at 151 (concluding that courts provide expectancy rather than reliance dainages because courts believe "Section 90 is about enforcing promises, not protecting rehiance"). But see W. David Slawson, The Role of Reliance im Contract Damages, 76 Cornell L. Rev. 197, 209, 236 (1990) (criticizing the "aesthetic of symmetry" that would match enforcement rationale with damages).

186 Cf. Fuller \& Perdue, supra note 11, at 53-54 (analyzing contract remedies from perspective of promisee's interests).

187 See Fried, supra note 60, at 18-21 (discussing the strong connection between promise and award of expectation dainages). But see Vincent A. Wellınan, Conceptions of the Common Law: Refleetions on a Theory of Contract, 41 U. Miani L. Rev. 925, 967-70 (1987) (criticizing Fried by citing supposed prevalence of nonexpectancy relief in moral obligation cases). 
Not surprisingly, those commentators, such as Professors Eisenberg and Braucher, who explain the moral obligation cases in terms of restitution also hold that recovery ought to be based on, or at least himited by, the value of the underlying moral obhigation. ${ }^{188}$ If, as they suggest, the promise matters only because it removes barriers to recovering what the promisee gave the promisor earlier, then the promisee should simply get back what she gave, or its value. The Second Restatement is even more aggressive than the commentators. Not only does it advocate limiting recovery to restitution on normative grounds, it indicates that recovery is so limited as a matter of positive law. ${ }^{189}$ Section 86 states that "[a] promise made in recognition of a benefit previously received . . . is binding to the extent necessary to prevent injustice" 190 and limits recovery by providing that "[a] promise is not binding under [Section 86] . . . to the extent that its value is disproportionate to the benefit" previously received by the promisor. ${ }^{191}$ The comments elaborate:

[W] here a benefit received is a liquidated sum of money, a promise is not enforceable under this Section beyond the amount of the benefit. Where the value of the benefit is uncertain, a promise to pay the value is binding and a promise to pay a liquidated sum may serve to fix the amount due if in all the circumstances it is not disproportionate to the benefit.... A promise which is excessive may sometimes be enforced to the extent of the value of the benefit, and the remedy may be thought of as quasi-contractual rather than contractual. ${ }^{192}$

188 See supra notes $119-23$ and accompanying text (discussing Eisenberg's position); Restatement (Second) of Contracts $\S 86 \mathrm{cmt}$. i (1979) (partial enforceinent); 1965 Proceedings, supra note 26, at 273 (emphasizing limited recovery) (remarks of Professor Braucher); see also Calamari \& Perillo, supra note 22, § 5-4, at 252-53 (apparently in accord); Goetz \& Scott, supra note 26 , at 1311,1312 \& n.133 (suggesting exchange-related rationale for limited damages).

189 See Restateinent (Second) of Contracts $\$ 86$ (1979); see also Wellman, supra note 187, at 968 (asserting that in moral obligation cases "the trend is toward using a different ineasure of damages than the expectation interest"). The Restatement indicates that recovery is so limited for promises made in recognition of a benefit previously conferred on the promisor by the promisee. In other inoral obligation cases, the Restatennent states simply that the prourise is enforceable, suggesting that recovery is measured by the promise. See Restatement (Second) of Contracts $\$ \S 82,83 \& 85$ (1979).

190 Id. $\S 86(1)$.

191 Id. $\S 86(2)$ (b); see also Gilinore, supra note 26 , at 74-75 \& n. 183 ("what Subsection (1) giveth, Subsection (2) largeiy taketh away").

192 Restatement (Second) of Contracts $\$ 86$ cint. i (1979). Professor Eisenberg notes that the exclusion oniy of "disproportionate" recovery may not always limit recovery to the amount of the benefit. Eisenberg, supra note 26, at 664 n.73. 
The consistent award of expectation damages seems at odds with the commentators' and the Restatement's explanation of the moral obhigation cases. Of course, in deciding on a remedy, courts may be moved by factors other than the principle underlying recovery. ${ }^{193}$ Thus, the reinedy awarded may not always reveal the reason courts grant a reinedy. ${ }^{194}$ Nevertheless, cases that present a clear choice between readily calculable expectation damages and restitution also present a clear choice between theories of recovery. Consider, for example, In re Hatten's Estate, ${ }^{195}$ one of the two cases the Second Restatement cites in connection with its stark assertion that partial enforcement is appropriate when the promise is disproportionate to the value of the previously conferred benefit. ${ }^{196}$ Citation of Hatten's Estate in this context is remarkable, for although expectation and restitutionary remedies were quite different in that case, the court chose expectation.

193 See Fuller \& Perdue, supra note 11, at 57-61; Slawson, supra note 185, at 236; Yorio \& Thel, supra note 16 , at $119-20,129-51$.

194 Various nonpromissory factors may dictate the award of expectation damages for the breach of promises made in recognition of moral obhigation, such as the virtual equivalence of expectation damages and restitution or difficulty in measuring the value of the benefit conferred. However, remedial choices are more likely to reflect underlying substantive policies here than in other areas of contract law. In a bargain, it will often be necessary to award expectation damages to protect the promisee's rehance interest, because reliance on a bargain may consist of forgoing alternative arrangements. See Fuller \& Perdue, supra note 11, at 60-61 (expectation dainages as surrogate for reliance); Yorio \& Thel, supra note 16 , at 119,150 . In promises based on moral obligation, however, the promisee does not respond to the promise; that is precisely why such cases are conceptually difficult. Thus, there is no reliance to protect by awarding expectation damages. For the same reason-i.e., that promises based on moral obhigation are not intended to influence the promisee's future behavior-refusing to award expectation damages in moral obhigation cases will not undermine the community interest in encouraging bargains and the wealth they produce. See Dawson, supra note 48, at 22-21; Fuller \& Perdue, supra note 11, at 61. But see Richard A. Posner, Gratuitous Promises in Economics and Law, $6 \mathrm{~J}$. Legal Stud. 411 (1977) (justifying enforcement of gratuitous promises on efficiency grounds); cf. Scott, supra note 165, at $360 \mathrm{n} .109$ (criticizing Posner's treatment of rescue cases).

Nor does it seem likely that courts grant expectation damages in moral obligation cases out of habit. The habit in these cases, such as it is, is to deny recovery entirely. If courts grant expectation relief in the relatively rare cases in which careful scrutiny of the promisee's interest in restitution leads them to act, it hardly seems likely that they are not cognizant of the type of remedy they are giving. The careful examination of moral obligation that typically precedes any recovery also makes it unlikely that courts choose expectation relief because of the difficulty of deternining a suitable restitutionary award.

195288 N.W. 278 (Wis. 1939).

196 See Restatement (Second) of Contracts $\S 86$ reporter's note (1979) (stating that illustration 12 to $\S 86$ comment $i$ is based on Hatten's Estate). 
In Hatten's Estate, the plaintiff, Beatrice Monsted, furnished meals and extended the privileges of her home and automobile to her family friend Wilham Hatten for twenty-five years. Hatten had requested these services, and he promised on several occasions in 1936 that Monsted would be well paid for what she did. On January 31, 1937, she prepared for Hatten, at his instruction, a promissory note for $\$ 25,000$, " "To be taken from my estate." "197 Monsted asked whether that was not a lot of money, and Hatten replied that it was not a lot for wliat slie had done. He then signed the note and gave it to lier. ${ }^{198}$ A few months later Hatten died and Monsted sued his estate on the note and in quantum meruit for services rendered, whicli slie alleged liad a reasonable value of $\$ 6,000$. After she abandoned lier quantum meruit claim, the court awarded $\$ 25,000$ on the note, plus interest. The estate unsuccessfully appealed on the ground that there was no consideration for the note. ${ }^{199}$ The Supreme Court of Wisconsin began its discussion of consideration by volunteeruig that Monsted's services were not worth $\$ 25,000$, but it empliasized that the question of their value was not before it. ${ }^{200}$ The action before the court was not Monsted's request for quantum meruit, but her claim for breaclı of promise. The court apparently regarded inquiry into the value of the services in this context to be a forbidden imquiry into adequacy of consideration. Moreover, the court cited a string of cases enforcing promises made in recognition of services previously rendered, notwithstanding tliat the promised amounts "'miglit be regarded as umiecessarily generous." "201 The only question was whetlier Hatten's promise was supported by consideration, and the court found that, under Wisconsin's "liberal rule," consideration could take the foru of moral obligation. ${ }^{202}$

Hatten's Estate pointedly rejects the position that the preexisting obligation that makes a promise enforceable also defines the appropriate remedy. The court acknowledged that the promise at issue clearly

197 Hatten's Estate, 288 N.W. at 281.

198 Id. at 282.

199 Id. at 280 .

200 Id. at 285.

201 Id. at 287 (quoting Citizens' Nat'l Bank v. Custis, 141 A. 556, 557 (Md. 1928)); see id. at 285-87.

202 Id. at 287. See generally Harold C. Havighurst, Services in the Home-A Study of Contract Concepts in Domestic Relations, 41 Yale L.J. 386, 396-97 (1932) (discussing enforcement of promises to pay made after services in the home have been rendered). 
exceeded the obhigation, but einphasized that the inequality was irrelevant. $^{203}$ On the contrary, the court borrowed from bargain analysis to find that the parties alone are to decide whether what the promisee gives-or, in these cases, has already given-is enough for what the promisor provides in return. ${ }^{204}$ The court's extensive discussion of the inequality between the obhigation and the promise and of the doctrine that inadequacy of consideration is no defense is particularly telling in hight of the abandoned quasi-contractual claim. Had Monsted provided services of indeterminate value, the $\$ 25,000$ figure might be seen as Hatten's approximation of the value of his unliquidated obligation. ${ }^{205}$ The value of the services was not indeterminate, lowever, for the plaintiff liad herself alleged that they were worth $\$ 6,000$, mucl less than what Hatten subsequently promised. The plaintiff's admission notwithstanding, the only question was whetlier slie could recover on the promise. Once the underlying obhigation was determined to be sufficient to trigger enforceinent, the promise was treated like any otlier enforceable promise. Inquiry into tlie value of tlie underlying obligation was just as mappropriate as inquiry into the value of consideration in the case of a bargained-for promise. ${ }^{206}$

According to the Restatement, if Hatten liad promised Monsted his entire estate, slie would not have been entitled to more than the reasonable value of her services. ${ }^{207}$ The reporter's note ${ }^{208}$ states that this conclusion is based on another Wisconsin case, In re Estate of

203 Hatten's Estate, 288 N.W. at 285-86.

204 Id. at 286.

205 The trial court may have found Hatten's $\$ 25,000$ promise to be binding on one or both of two grounds: that it was a promise of a liquidated sum in satisfaction of an unliquidated obligation, or that it was a promise supported by moral obligation. See 288 N.W. at 285; cf. 1A Corbin, supra note 27, § 211 ("An Existing Indebtedness or Obligation Supports a New Co-extensive Promise"). The supreme court, however, did not accept or even discuss the unliquidated-obligation approach to the case. Cf. Farnsworth, supra note $22, \S 2.8$, at 59 (reasoning that Monsted had no legal claim for lier services prior to the promise).

206 See Restatement (Second) of Contracts $\$ 79$ (1979) ("If the requirement of consideration is inet, there is no additional requirenient of . . . eqnivalence in the values exchanged. ...").

207 Id. $\$ 86 \mathrm{cmt}$. i, illus. 13. The Restatennent's position in regard to Hatten's Estate may be that there is no disproportion between a $\$ 6,000$ benefit and a $\$ 25,000$ promise or that only gross disproportion will justify limiting recovery. Neither position can be justified, lowever. As for the first, $\$ 25,000$ is clearly disproportionate to $\$ 6,000$. As for the second, the restitutionary argument would restrict recovery to the benefit whenever the promise exceeded the benefit, not merely whenever the promise greatly exceeded the benefit. See Eisenberg, supra note 26 , at 664 n.73.

208 Restatenient (Second) of Contracts § 86 reporter's note (1979). 
Gerke. ${ }^{209}$ In that case, the plaintiff, May Desmimovich, provided Herman Gerke with meals for a number of years and did a variety of domestic chores. Herman repeatedly stated that when he died everything would go to May. After Herman died intestate, May sued, claiming alternatively either Herman's whole estate under the promise, or $\$ 2,338$, the reasonable value of her services. ${ }^{210}$ The court cited Hatten's Estate for the proposition that a moral consideration will support a promise to pay for services previously rendered, but held that May was entitled ouly to the value of the services that she had furnished. ${ }^{211}$ In so holding, however, the court did not retreat from Hatten's Estate and declare restitutionary recovery appropriate im moral obligation cases - on the contrary, the court seemed to take expectation to be the standard remedy. As the court reasoned, the oral promise could not be enforced because to "measure recovery by the value of the estate would circumvent the statute of wills."212 Thus, the court limited May's recovery because Hernian's promise of a legacy miphicated the statute of wills, a public pohicy unrelated to either promise or restitution.

Hatten's Estate and Gerke, the only cases the Restatement cites in support of the proposition, ${ }^{213}$ hardly show that recovery for breach of a promise based on moral obligation is limited to the value of the benefit previously conferred. ${ }^{214}$ In fact, courts consistently award

20973 N.W.2d 506 (Wis. 1955).

210 Id. at 507.

211 Id. at 508-09.

212 Id. at 509.

213 See also Calamari \& Perillo, supra note $22, \S 5-4$, at $251 \&$ n.23 (citing only Gerke for the proposition that "a number of cases take the view that the promise will be enforced only to the extent that it is not disproportionate to the value of the services" previously rendered at request).

214 Some support for the proposition that the underlying moral obligation sometimes limits recovery may be found in cases holding that a promise to pay a debt barred by the statute of limitations is binding only to the extent of the preexisting debt. See 1A Corbin, supra note 27, \$ 212; see also infra notes 221-29 and accompanying text (discussing remedies for promises to pay barred debts). Some state statutes purport to limit recovery in light of the underlying obligation. See Henderson, supra note 24, at 1129-31. For example, the California Civil Code provides: "An existing legal obligation resting upon the promisor, or a moral obligation originating in some benefit conferred upon tlie promisor, or prejudice suffered by the promisee, is also a good consideration for a promise, to an extent corresponding with the extent of the obligation, but no further or otherwise." Cal. Civ. Code $\S 1606$ (West 1982). These statutes apparently are rarely applied in accordance with their terms. See Henderson, supra note 24 , at 1129-31. In one case, the court invoked the California statute as a ground for limiting recovery to the value of services previously rendered rather than the amount of the proinise. 
expectation damages, and they do so even when expectation exceeds the value of restitution. ${ }^{215}$ Once agam, Hargroves, the Georgia paternity case, is nistructive. ${ }^{216}$ As in Hatten's Estate, the court explamed that it could not limit recovery without an inappropriate inquiry into the adequacy of consideration: "Courts will not undertake to nieasure the consideration, nor to circumscribe it by any definite or prescribed bounds ... Is the consideration legal? If so, its adequacy is a niatter for the determination of the parties themselves . . ."217 In enforcing the father's promise, the court based recovery on the promise, not on the natural obligation.

Those who nramtain that recovery in these cases is based on the underlying inoral obligation rather than the promise might argue that a father's promise of support cures legal impediments to enforcing his noral obligation to support his children. In Hargroves, however, the court did not suggest that it was awarding recovery on the underlying obligation. On the contrary, the judge simply enforced the promise. The elaborate treatment of the consideration issue in Hargroves and in other cases ${ }^{218}$ suggests that the promise itself is critical. Similarly, the award of expectation damages when the promise clearly exceeds the

See Herbert v. Lankershim, 71 P.2d 220, 254 passim (Cal. 1937). Other grounds, however, contributed to the court's unwillingness to enforce the proimise, including undue influence and the possibility that the promisor's signature was forged. Id. at 228-29. Other California cases have awarded amounts in excess of the underlying obligation. See infra note 215 .

215 See, e.g., Williams v. Kinsey, 169 P.2d 487, 499-500 (Cal. Dist. Ct. App. 1946) (holding that inoral obligation to pay commission was sufficient consideration for subsequent promise to pay substantially inore); Salsbury v. Northwestern Bell Tel. Co., 221 N.W.2d 609, 613 (Iowa 1974) (enforcing full amount of charitable subscription even thougl plaintiff had no restitutionary claim); In re Hatten's Estate, 288 N.W. 278 (Wis. 1939); Citizens' Nat'l Bank v. Custis, 141 A. 556, 557 (Md. 1928) ("It would not be proper to hold that the note was without consideration because the reward it provided might be regarded as unnecessarily generous."); In re McAskill's Estate, 257 N.W. 177, 179 (Wis. 1934) ("Even though the value of the services inay be deened by others to be less than the promised amount, that does not necessarily warrant liolding that there is a failure, or partial failure, of consideration."); Sheldon v. Blackman, 205 N.W. 486, 489 (Wis. 1925) ("If he debiberately chose to pay inore than the services were really wortll, he had the riglit to do so."); cf. Wilson v. Wilson, 352 P.2d 725, 729-31 (Cal. 1960) (finding that moral obligation to support family and pay notes was consideration for promise to pay inore than the amount of notes).

216 See supra notes 158-62 and accompanying text.

217 Hargroves v. Freeinan, 12 Ga. 342, 350 (1852) (citation omitted); see also Hays v. McFarlan, 32 Ga. 699, 703 (1860) (quoting same).

218 See, e.g., Thorpe v. Collins, 263 S.E.2d 115, 117-18 (Ga. 1980); Citizens' Nat'l Bank v. Custis, 141 A. 556, 557 (Md. 1928); Todd v. Weber, 95 N.Y. 181, 190-92 (1884); Hatten's Estate, 288 N.W. at 285-87; McAskill's Estate, 257 N.W. at 179; Sheldon, 205 N.W. at 489; Annotation, supra note 155 , at $\S 9$. Even the leading exponent of the restitutionary theory of 
value of the underlying moral obhgation mdicates that a finding of sufficient moral obligation operates as a trigger for enforcing promises, rather than promise operating as a trigger for enforcing moral obhgations. ${ }^{219}$

The triggering function of moral obligation is also apparent when courts face the other side of the equivalency question-promises for less than the moral obhgation. Here again, courts typically award the ainount of the promise, notwithstanding that more would be required to satisfy the underlying obligation. ${ }^{220}$ This situation frequently arises in comiection with promises to pay debts barred by the statute of limitations. The First Restatement's fainous hist of promises that are binding without consideration began not with Section 90 , but with debtors' promises to pay debts barred by the statute of limitations. ${ }^{221}$ Such promises have long been binding even when not supported by consideration. ${ }^{222}$ When the promise is to pay the ainount of the debt, expectation damages may serve both promissory and restitutionary goals: the promisor is held to his promise and the creditor gets the amount of the benefit conferred when the debt was created. ${ }^{223}$ When the debtor promises to pay less than the amount of the barred debt,

the moral obligation cases notes that the opinions consistently speak of consideration. Henderson, supra note 24 , at 1125 n:37.

219 The award of expectation for charitable subscriptions that are not supported by consideration or reliance slows that courts respond to more than restitutionary or reliance interests and award more than restitutionary or reliance damages in moral obligation cases, for charities often lave no restitutionary or reliance interest in subscriptions. Sec Yorio \& Thel, supra note 16 , at 153 .

220 See, e.g., In re Cirillo's Estate, 114 N.Y.S.2d 799, 801 (Surr. Ct. 1952) (If a child's "claim is based upon sucl an agreement [imstead of upon the paternity statute] ... the agreement itself measures the linits of the putative father's liability. Neitler he nor his estate after deatl may be held for more than he lias agreed to pay.").

221 Restatement of Contracts $\S 86$ (1932).

222 See, e.g., Born v. La Fayette Auto Co., 145 N.E. 833, 836 (Ind. 1924); Gillingham v. Brown, 60 N.E. 122, 122 (Mass. 1901); Hart v. Boyt, 54 Miss. 547, 548 (1877); Restatement (Second) of Contracts $\S 82(1)$ (1979); see also 1A Corbm, supra note 27, $\$ 211$, at 278 ("It is universally leeld that a past debt that has been barred by the statute of limitations is a sufficient basis for a new promise."); Murray, supra note $26, \S 67(\mathrm{~A})(1)$ (discussing past acts as consideration). See generally Calamari \& Perillo, supra note $22, \S \S 5-5,5-7$ (discussing effect of and rationale behind rule concerning proinises to pay barred debts); $1 \mathrm{~A}$ Corbin, supra note $27, \S \S 214-219$ (discussing enforcenient of new promises to pay antecedent debts and revival of reniedies based on partial payments); Farnsworth, supra note $22, \S 2.8$ (discussing moral obligations exception to bargain rule); 1 Williston, supra note $27, \S \S 160-178$ (outlining the early law and nodern rule governing the enforceability of a promise to pay past indebtedness).

223 More accurately, the creditor gets not the value of the benefit he conferred, but the amount the debtor originally promised to pay for the benefit. 
however, courts have to choose between the plaintiff's rights as either creditor or promisee. When faced with the choice, courts consistently respond to promise by enforcing the promise according to its terms rather than reviving the debt.

A promise to pay part of a barred debt is binding, but it does not revive the whole debt. For exanple, a promise to pay $\$ 300$ on a $\$ 1500$ debt on which the statute has run is bimding only to the extent of $\$ 300.224$ If the plaintiff's case were based on the barred debt, that is, the underlying obligation, with the promise serving only to vitiate the technical defense of the statute of limitations, the plaintiff would be entitled to recover the whole amount of the debt. The fact that courts consistently limit the promisee/creditor's recovery to the anount of the promise shows that recovery is based on the promise, not on the antecedent debt. ${ }^{225}$ Similarly, a debtor who promises payinent on certain terms or subject to conditions is not bound except on those terms or conditions. ${ }^{226}$ Yet even a conditional acknowledgment would seem sufficient if the courts were concerned only with the problems that the statute of limitations addresses. Here again, the rule allows promisors to hide behnid conditions of their own making. 227

224 Brown v. Hebb, 175 A. 602, 606 (Md. 1934); see also Lambert v. Doyle, 43 S.E. 416, 416 (Ga. 1903) (promise to pay existing debt is enforceable to the extent that acknowledgment clearly expresses an intent to pay and clearly identifies the note or amount to be renewed); McDonald v. Grey, 29 Tex. 80, 83 (1867) ("The terms upon which the debtor predicates his promise ... are entirely within his own option and discretion ...."); Restatement (Second) of Contracts $\S 82(1)$ (1979) ("A promise to pay all or part of an antecedent . . indebtedness . . . is binding . ..."); id. $\S 82$ illus. 7 (illustrating rule); Farnsworth, supra note 22, $\S 2.8$, at 55 ("II]f the promise is a conditional one or is one to pay only part of the debt, it is enforceable only to that extent.").

225 See Farnsworth, supra note $22, \S 2.8$, at 55 ("Since the action is based on the new prounise, rather than on the barred debt, recovery is limited to the terms of that promise.").

226 See, e.g., Shepherd v. Thompson, 122 U.S. 231, 239-40 (1887) (holding that creditor's rights are measured by the new promise, not by the old debt); Jones v. Jones, 242 F. Supp. 979 , 982 (S.D.N.Y. 1965) (applying New York law); Restatement (Second) of Contracts § $91 \&$ illus. 1 (1979); 1 A Corbin, supra note $27, \S 215$, at 295-96; id. $\$ 216$, at $300 ; 1$ Williston II, supra note $64, \S \S 158,179,182$.

227 See $1 \mathrm{~A}$ Corbin, supra note $27, \S 215$, at 294 :

Although a man ought to pay his barred debts, he is protected on grounds of public policy against direct judicial enforcement. He need not dispense with this protection at all; and, if he is willing to do away with it, he can do this in part only, instead of in whole, and he can limit his promise by providing for new conditions precedent to duty. 
The rule that a promise taking a debt out of the statute of limitations is enforceable only "in accordance with its own terms" 228 reveals the promissory basis of recovery. As the courts that shaped the rule recognized, the obligor's conditions are binding on the obligee because recovery is based on the new promise and not the old debt:

I know there are many old cases, which consider the statute as founded on the presumption of payment; that whatever repels that presumption, is, in legal effect, a promise to pay the debt; and that, though such acknowledgment is accompanied with only a conditional promise, or even a refusal to pay, the law considers the condition or refusal void, and the acknowledgment itself as an unconditional answer to the statute. But the more recent, and, I think, the more rational, decisions take a different view of the case. They consider this a statute of repose, which ought to receive from the courts a fair and just support. They consider the acknowledgment a new promise, not a continuance of the old; and that to revive the debt, it must be unqualified and unconditional. ${ }^{229}$

In other contexts as well, an obhgor who makes a conditional promise to honor her obhigation is bound solely to her promise. ${ }^{230}$ If the promise is conditional or performable only at a future time, "performance becomes due only upon the occurrence of the condition or upon the arrival of the specified time."231 Yet the promise, subject to the conditions, is binding when made. ${ }^{232}$ Courts enforce the promise, not the underlying obligation: the promisor is bound by the commitment she makes and only by that commitinent.

228 Jones v. Jones, 242 F. Supp. 979, 982 (S.D.N.Y. 1965) (quoting 1A Corbin, supra note $27, \S 214$, at 289).

229 Farmers Bank v. Clarke, 31 Va. 603, 606 (Va. Ct. App. 1833) (opinion of Carr, J.); see also Cleinentson v. Williams, 12 U.S. (8 Cranch) 72, 74 (1814) (Marshall, C.J.) (noting that prior decisions have held that acknowledgment revives a prior debt but concluding that mere acknowledgment without more does not prevent an old debt from being barred).

230 See, e.g., In re Cirillo's Estate, 114 N.Y.S.2d 799, 801 (Surr. Ct. 1952) (construing terms of putative father's promise to support child).

231 Restatement (Second) of Contracts $\$ 91$ (1979); see also 1A Corbin, supra note 27, $\S 222$, at 324 ("If the new promise is itself limited or conditional, no action hies against the debtor unless the condition has been performed."); id. $\S 227$, at 337-38 (new promise only enforceable based on new terms); cf. Goetz \& Scott, supra note 26, at 1311-12 (suggesting rationale for permitting promisor to attach conditions).

232 See Restatement (Second) of Contracts $\S 91$ (1979). 


\section{A Promise Is Required}

The imperative of promise explains the force courts sometimes accord nonrestitutionary obligations; the routine award of expectancy rehef, even when expectation exceeds the value of the underlying moral obligation; and the enforcement of promises according to their terms. If courts were moved only by the imperative of benefit received, promises made in recognition of moral obligation would have less legal effect than they do: nonrestitutionary obligations would not inove courts to act, and courts would not award expectation dainages in excess of the value of the underlying obligation. At the same time, tlie regime of promise is in some ways more restrictive than that of restitution. For exainple, courts refuse to award the full recovery indicated by the imiperative of restitution when the obligor promises less than full restitution. ${ }^{233}$ More broadly, the absence of a promise may prevent the beneficiary of a moral obhigation from recovering at all; that is, a promise is an essential condition of any recovery. ${ }^{234}$

Under the conventional theory that recovery is based on the underlying moral obligation, a promise would seem to be only one way to prove the moral obhigation, not a condition of recovery. ${ }^{235}$ Yet a

233 See discussion supra Part II.B.

234 Moreover, to be enforced on the basis of past consideration, the promise must be induced by the moral obligation. See 1 A Corbin, supra note $27, \S 210$, at 275; see also Goetz \& Scott, supra note 26 , at 1312 n.133 (discussing mixed motives in current $\$ 86$ cases). The fact that promises are enforced on the basis of antecedent moral obligation only when they are made in response to and induced by the operative obligation suggests that courts are not looking for excuses to enforce such obligations.

235 A promise to honor an obligation may help prove the existence of a powerful obligation. If recovery is based on the obligation, however, the obligee ouglit to be able to recover regardless of how she proves the obligation-whether by a promise or by the obligor's nonpromissory acknowledgment of its existence.

Contrast the position of Professor Fuller, who saw moral obligation and promise acting in tandem:

In refutation of the notion of "moral consideration" it is sometimes said that a moral obligation plus a mere promise to perform that obligation can no more create legal liability than zero plus zero can have any other sum than zero. But a mathematical analogy at least equally appropriate is the proposition that one-lialf plus one-half equals one.

Fuller, supra note 99, at 822; see also supra notes 98-101 and accompanying text (discussing Fuller's explanation of moral obligation cases). Fuller was responding to those who denied that promises in recognition of moral obligation could be binding at all, but the same response could be made to those who would ground recovery in the obligation and not the promise. 
promise is required, as even restitutionary theorists acknowledge. ${ }^{236}$ The substantive law of restitution permits recovery without promise in many cases, but in numerous other cases, including those of the sort discussed in this Article, courts act only after the inoral obligor promises to do what she recognizes that she ought to do. ${ }^{237}$ As Corbin stated, '[i]n all 'past consideration' cases, the new promise is a necessary factor in the plaintiff's cause of action."238

Consider once again promises to pay debts barred by the statute of limitations. Such promises are routinely enforced, but a inere acknowledgment of a debt does not oblige the debtor to pay. ${ }^{239}$ Yet an acknowledgment would seem the equal of a promise for purposes of satisfying the evidentiary concerns behind the statute and of waiving the statutory pohicy of repose. Courts insist on a promise, however, indicating that recovery is based on a new commitinent, not on resurrection of the old debt. ${ }^{240}$ To be sure, a promise may be miphed

236 See, e.g., Gilmore, supra note 26, at 74 (Section 86 "is far from going the whole hog on the unjust enrichment idea. For one thing, the ungrateful recipient may keep whatever he has received without paying for it so long as he is clever enough to avoid making a 'promise' to repay."); Eisenberg, supra note 26, at 664 (arguing that recovery should be limited to the lesser of the amount of the promise or fair compensation). For a recent discussion of the centrality of promise in contract law, see Peter Limzer, Uncontracts: Context, Contorts and the Relational Approach, 1988 Ann. Surv. Am. L. 139; see also id. at 199 (commentary of Steven J. Burton and Jonathan Eddy thereon); id. at 213 (Linzer's reply).

237 Cf. $1 \mathrm{~A}$ Corbin, supra note $27, \$ 230$, at 340 ("Lord Mansfield held that an informal promise is enforceable if the performance promised is one that the promisor is already under a moral duty to the promisee to render."); Simpson, supra note 45 , at 457 :

[C]entral to the theory of consideration [is this]: the court is not prepared to hold the defendant liable for breaking a promise to do somethmg unless it can find some reason for imposing hability over and above the mere fact that a promise has been given. To put the point in a siightly different way: a promise to do $X$ is ouly actionable if it can be said, somewhat loosely no doubt, that the promisor ought to have done $\mathrm{X}$ anyway.

238 1A Corbin, supra note $27, \S 219$, at 313.

239 Shepherd v. Thompson, 122 U.S. 231, 235 (1887); Clementson v. Wiliiams, 12 U.S. (8 Cranch) 72, 74 (1814); Northwestern Brewers Supply Co. v. Vorhees, 203 S.W.2d 422, 425 (Mo. 1947); 1 Williston II, supra note 64, § 161; cf. Faison v. Bowden, 76 N.C. 425, 426 (1877) (criticizing revival of debts on basis of "vague acknowledgments or careless promises," but basing refusal to enforce on fact that acknowledgment was not made to creditor himself).

240 See 1A Corbin, supra note 27, $\$ 219$ (discussion headed "The Cause of Action Consists of Both Old Debt and New Promise"). 
by an acknowledgment of the debt ${ }^{241}$ or by partial payment. ${ }^{242}$ Nonetheless, the fact that courts msist on finding a promise rather than openly basing recovery on the acknowledgment is itself telling evidence of the power of promise. Moreover, the promise requirement is not merely rhetorical. If the debtor couples her acknowledgment with a clear statement that she will not pay her barred debt, so that a promise cannot be implied, the creditor cannot recover. ${ }^{243}$ Similarly, the refusal to imply a promise from an involuntary acknowledgment ${ }^{244}$ or an involuntary partial payment ${ }^{245}$ underscores that courts are moved by the obhigor's renewed commitment, not by the underlying obligation.

The proimise requirement may be even more stringent for other promises based on moral obhigation. Thus, an adult's acknowledgment of the executory contracts of her infancy does not make them binding, nor does partial payment, although a promise may be imphed from either. ${ }^{246}$ Courts typically refuse to imply a promise to pay a debt discharged in bankruptcy from an acknowledgment or partial payment, but insist on an express promise. ${ }^{247}$ Moreover, in many jurisdictions statutes provide that promises in recognition of a variety

241 Dyer v. Lowe, 29 So. 2d 324, 325 (Miss. 1947); Restatement (Second) of Contracts $\S 82$ (2)(a) (1979); 1A Corbm, supra note $27, \S 216$, at 297; 1 Williston II, supra note $64, \S 166$, at 669 .

242 Restatement (Second) of Contracts $\S 82(2)(b)$ (1979); 1A Corbin, supra note 27, $\$ 217$, at 301-02; 1 Williston II, supra note $64, \S 174$, at 686 .

${ }^{243}$ Sanderson v. Sanderson, 237 N.Y.S.2d 922, 922-23 (App. Div. 1963); Restatement (Second) of Contracts $\S 82$ illus. 11 (1979); 1A Corbin, supra note 27, $\$ 217$, at 303; 1 Williston II, supra note 64, $\S \S 161,170$; see also Bell v. Morrison, 26 U.S. (1 Peters) 351, 362 (1828) ("If there be accompanying circumstances, which repel the presumption of a promise or imtention to pay ... they ought not to go to a jury as evidence of a new promise ...."); Wilson v. Walters, 151 P.2d 685, 686 (Cal. Dist. Ct. App. 1944) (implying that the law will not enforce a promise to pay evidenced by an acknowledgment of an existing debt where such a written acknowledgment contains "intimation of an intent to refuse paynent").

244 See Restateinent (Second) of Contracts $\$ 82(2)(a)$ (1979) (listing only voluntary acknowledgments as having the effect of promises).

245 See id. $\S 82$ illus. 13; 1A Corbin, supra note 27, $\$ 217$, at 303-06 (stating that partial payment must be voluntary to imply a promise); 1 Wilhston II, supra note $64, \S 175$, at $692-93$ (same); cf. McLaren v. McMartin, 36 N.Y. 88, 88 (1867) (liolding that part payment by executor or administrator will not revive debt of decedent barred by statute of limitations).

246 Calamari \& Perillo, supra note 22, § 8-4, at 312-13.

247 Restatement (Second) of Contracts $\$ 83$ (1979) ("An express promise to pay . . indebtedness . . . is binding.") (emphasis added); id. $\S 83 \mathrm{cmt}$. a; $1 \mathrm{~A}$ Corbin, supra note 27 , $\S 222$, at 323 ; 1 Williston II, supra note $64, \S 158$, at $656-57$; see also 11 U.S.C. $\S 524$ (c) (1991) (restricting effeet of promise to pay discharged debt). 
of moral obligations are enforceable only if contained in a signed writing. ${ }^{248}$

Courts liave also paid close attention to the threshold requirement of promise im child support cases. ${ }^{249}$ For example, im New York, altliougl a fatlier's promise to support his nonmarital child was enforceable, ${ }^{250}$ acknowledgment of paternity did not itself create a legally enforceable support obligation. ${ }^{251}$ Furtlier evidence of the force of promise lies in the rule tliat once a man promises to support his putative children, lie cannot avoid his promise by showing that lie was not in fact the fatlier; ${ }^{252}$ if a cliild's recovery on a fatlier's promise of support were based on the underlying inoral obligation, then the promisor would be entitled to question tliat obligation. The bottom line-disturbing if not surprising-seems to be tliat common law courts found a man's obligation to keep his word more compelling than his obligation to support his children. ${ }^{253}$

248 See, e.g., N.Y. Gen. Obl. L. \$ 17-101 (McKinney 1989) (providing that a signed writing of acknowledgment or promise is the only evidence of a new or contimuing contract sufficient to take an action out of the statute of himitations); see also Gillingham v. Brown, 60 N.E. 122, 123 (Mass. 1901) (Applicable statute "provides that no acknowledgment or promise [to pay barred debt] shall [be enforceable] ... unless contained in some writing ... ."); Restatement (Second) of Contracts $\$ 82 \mathrm{cmt}$. a (1979) (noting that most states liave statutory writing requirement for promises to pay debts barred by the statute of limitations); id. $\S 83 \mathrm{cmt}$. a (stating that only a few states require promises to pay debts discharged in bankruptcy to be in writing); id. $\$ 85 \mathrm{cmt}$. b (noting that a few states inpose statutory writing requirements for promises of former infants to pay voidable debts); $1 \mathrm{~A}$ Corbm, supra note 27, $\$ 223$ (discussion entitled "Must the New Promise Be in Writing?"); Calamari \& Perillo, supra note 22, § 8-4, at $312 \mathrm{n} .56$ (listing states that have enacted statutes requiring written ratification); 1 Williston II, supra note 64, $\$ 151$, at $645 \mathrm{nn} .9-10$ (citing English and American statutes requiring same); id. $\S 164$ (discussing issues of statutory construction in jurisdictions requiring a writing); cf. 11 U.S.C. $\$ 524(c)$ (1991) (requiring fornalities so that agreenent to pay debt discharged in bankruptcy will be held enforceable).

249 See, e.g., Todd v. Weber, 95 N.Y. 181, 189-90 (1884) (reversing referee's finding that father did not promise to support illegitimate child); In re Cirillo's Estate, 114 N.Y.S.2d 799, 801 (Surr. Ct. 1952); 2 Kent, supra note 157, at *215 n.b ("[T] he putative father is not liable except upon an express promise....").

250 Weber, 95 N.Y. at 189.

251 Moncrief v. Ely, 19 Wend. 405, 405 (N.Y. 1838); see also Furillio v. Crowther, 29 Rev. Rep. 467,468 (K.B. 1826) (holding that payments for support do not create legal obligation to continue support).

252 Hays v. McFarlan, $32 \mathrm{Ga} .699,703$ (1861).

253 Some states now require fatliers to support their clildren by statute. Even in those states, however, promises to provide support still may be enforced.

The importance of the tenor of the times is acutely apparent in moral obligation cases. Indeed, if no universal rule of sufficient moral obligation can be stated, it is because "court action will vary with the multitude of human inpulses, especially witl changing tides of 
The importance of promise is similarly well illustrated by a series of Iowa Supreme Court cases arising from a college fund-raising campaign. In the first two cases, the subscriber signed a pledge card that read " $I /$ we intend to subscribe to the College Founder's Fund the sum of . . .."254 The court held in both cases that the subscription was unenforceable because the pledge card expressed an intention to pay and was not a proimse. ${ }^{255}$ In the third case, Salsbury v. Northwestern Bell Telephone Co., ${ }^{256}$ the subscriber did not sign the standard pledge card, but its agent mailed a letter stating that "the contribution froin Northwestern Bell . . . has been approved" and the " $\$ 15,000$ contribution will be made over a three year period, in three equal payments."257 Citing a policy of favoring charities, the court held that the defendant was bound by the subscription. ${ }^{258}$

The public policy rationale offered in Salsbury is wholly unpersuasive as a way of distinguishing these cases. ${ }^{259}$ Not only was the plaintiff in all three cases a charity, but it was the very same charity. The real distinction between Salsbury and its predecessors is the quality of the defendant's commitment. Rather than expressing a mere intention to pay, the letter in Salsbury constituted a promise to make a contribution. ${ }^{260}$ In fact, in jurisdictions like Iowa in which charitable subscriptions are enforceable without consideration or detrimental rehance, the presence of promise is hiterally the only question at issue.

community opinion." 1A Corbin, supra note $27, \S 230$, at 344 . A father's obligation to support lis nonmarital children may seem more powerful today than it did in the past, and the policies against enforcing the obligation-for exanple, concern for the institution of narriage and related property interests-nuay seen less compelling. See Weber v. Aetna Cas. \& Sur. Co., 406 U.S. 164, 167-76 (1972) (carefully scrutinizing statutes that place exceptional burdens on nonmarital children). But see Lalli v. Lalli, 439 U.S. 259, 266-76 (1978) (upholding statute that places greater procedural burden on nonmarital children seeking to inherit because of state interest in orderly transition of property). Corbin saw in the legal treatment of paterual obligation a neat lesson in the temporality of legal rules and their foundation in transitory social nores: "as soon as a moral obligation of this sort coines to be generally recognized in a community, it is rapidly turned into a legal obligation without the necessity of a promise." $1 \mathrm{~A}$ Corbin, supra note $27, \S 231$, at 348 .

254 Pappas v. Bever, 219 N.W.2d 720, 721 (lowa 1974); Pappas v. Hauser, 197 N.W.2d 607, 609 (lowa 1972).

255 Bever, 219 N.W.2d at 721-22; Hauser, 197 N.W.2d at 612-13.

256221 N.W.2d 609 (Iowa 1974).

257 Id. at 610.

258 Id. at 612-13.

259 See supra text accompanying notes $175-76$ (discussing public pohicy rationale).

260 See Salsbury, 221 N.W.2d at 610 ("The trial court held the letter was a prounissory undertaking."). 
The charitable subscription cases, like the antecedent-debt and childsupport cases, demonstrate that courts require a promise before awarding any recovery based on felt moral obligation.

\section{Conclusion}

According to the conventional explanation of promises based on an underlymg moral obligation, the promise is not important because the promisor makes a commitment, but because the promise in one way or another alleviates barriers to enforcement of the moral obligation. ${ }^{261}$ Our thesis, on the other hand, is that tle promise is important precisely because of the commitment it embodies. We agree that courts study the underlying moral obligation, but we think they do more. We have shown that the conventional explanation understates the class of moral obligations that move courts to enforce promises and that courts decide $\mathrm{m}$ favor of enforcement despite the absence of restitutionary interests. Yet our criticism of the conventional explanation is more fundamental than a quarrel with its definition of operative inoral obligation. When courts examine the moral obhigation underlying a proimse, they ask whether it is sufficiently compelling to justify intervention, but they do not attempt to quantify the obligation. On the contrary, a judicial finding that the moral obligation underlying a promise is sufficient triggers enforcement of the promise through the award of expectation damages.

Furthermore, restitutionary obligations based on benefit conferred are only one of several types of preexisting obligation that may trigger the judicial impulse to enforce a promise. Unfortunately, however, the power of restitutionary primciples to explain some of the legal issues in this area has led commentators to assume that when courts enforce promises based on felt moral obligation, they are effecting some sort of "promissory restitution."262 This has led to understatement of the class of moral obligations that are likely to move the courts, ${ }^{263}$ to misapprehension of the remedy awarded once courts are

261 See supra Part I; see also Calamari \& Perillo, supra note 22, § 5-8, at 258 (The rule that promises to perform a voidable duty are enforceable "may also be explained on grounds other than the presence or absence of consideration. A voidable promise gives the promisor the right to elect to avoid or to affirm the promise. In promising to make payment he has given notice of his election not to exercise his power of avoidance.").

262 See Henderson, supra note 24, at 1118.

263 See discussion supra Part II.A. 
moved to act, ${ }^{264}$ and to underestimation of the importance that courts attach to proimise im these cases. ${ }^{265}$ More broadly, the restitutionary explanation figures prominently in the argument that contract law im general is concerned only with protecting proimisees' restitutionary and rehance interests. ${ }^{266}$ Yet courts respond to promise in this area and refuse to respond when there is no promise. ${ }^{267}$ Far from evidencing the death of contract, ${ }^{268}$ the judicial treatment of promises made in response to felt moral obligation shows that courts continue to be moved by the impulse to enforce proinises.

264 See discussion supra Part II.B.

265 See discussion supra Parts II.B, II.C.

266 See discussion supra Part I; see also Gilmore, supra note 26:

As we might expect, the refusal to give protection in the "benefit conferred" cases has been gradually suffering a reversal. ... The rejection of classical theory has thus been proceeding, albeit in a confused and sprawling pattern, on the benefit side as well as on the detriment side.

This uneven development is neatly caught for us in a new section which has been added to the Restatement (Second) as [§ 86]. ...

... Restatement (Second), as least in [ $\$ 86]$, is characterized by the same "schizophremic quality" for which Restatement (First) was so notable. ... The principal thing is that Restatement (Second) gives overt recognition to an important principle whose existence Restatement (First) ignored and, by implication derned. By the time we get to Restatement (Third) it may well be that [§ 86] will have flowered like Jack's beanstalk in the same way that $\S 90$ did between Restatement (First) and Restatement (Second).

Id. at 73-76 (footnote oinitted). Sec also Henderson, supra note 24, at 1117-19 (discussing $\S 86$ 's einphasis on "promissory restitution").

267 See discussion supra Part II.C.

268 See generally Gilmore, supra note 26 , at 87 , passim (discussing the dechine and fall of "contract" as it becomes reabsorbed into the mainstream of "tort"). 
